\title{
A Novel Intelligent Manufacturing Mode With Human-cyber-physical Collaboration and Fusion in the Non-Ferrous Metal Industry
}

\section{Qing Liu}

Tongji University

Min Liu ( Imin@tongji.edu.cn )

Tongji University

\section{Zichun Wang}

Tongji University

\section{Feng Yan}

CINF Engineering Corporation Limited, Changsha

\section{Yingyi Ma}

Guixi Smelter, Yingtan

\section{Weiming Shen}

Huazhong University of Science and Technology

\section{Research Article}

Keywords: non-ferrous metal industry, intelligent manufacturing mode with human-cyber-physical collaboration and fusion, product \& ecosystem service platform, sustainable business model, digital twin

Posted Date: July 1st, 2021

DOl: https://doi.org/10.21203/rs.3.rs-653224/v1

License: (c) (i) This work is licensed under a Creative Commons Attribution 4.0 International License. Read Full License

Version of Record: A version of this preprint was published at The International Journal of Advanced Manufacturing Technology on November 4th, 2021. See the published version at https://doi.org/10.1007/s00170-021-08250-5. 


\section{Abstract}

The non-ferrous metal industry is one of the most important part in China's process industry, and has an extremely important strategic position in national economy. However, in the smelting process of nonferrous metal, there still exists many problems: 1) the production process of non-ferrous is long, the utilization rate of resource and energy is low; 2) the large amount of waste discharge in the production process has caused prominent environmental protection issue; 3 ) product homogeneity is serious and the added value is low. To solve these problems, we constructed a novel intelligent manufacturing mode with human-cyber-physical (HCP) collaboration and fusion from three aspects: 1) intelligent manufacturing system with HCP collaboration and fusion, 2) product service system based on ecosystem platform, and 3) sustainable business model, to realize the safe, efficient and green production for the non-ferrous metal smelting process. In the case study on the largest copper smelting enterprise in the world, the digital twin based manufacturing system collaborative platform architecture, product \&service system framework, and sustainable business model canvas are built by the proposed intelligent manufacturing mode with HCP collaboration and fusion.

\section{Introduction}

Non-ferrous metals are basic raw materials for developing the national economy and strategic materials for the national defense and military industries. China's non-ferrous metal production and consumption ranked first in the world for 18 consecutive years. It is a non-ferrous metal power worthy of the name and continues to grow. As one of the most important part in China's process industry, the non-ferrous metal industry has strong development momentum and is important for powerful manufacturing countries with considerable strategic positions. Currently, the main process and equipment for non-ferrous metal smelting in China are at the advanced level globally, and a relatively complete modern non-ferrous metal industrial system has been formed(Yuan et al., 2018).

However, as a whole, china is not a strong country in the non-ferrous metal industry, primarily due to the following problems: 1) the smelting process of non-ferrous metal is long and there is correlation coupling between different processes, in which manufacturing data \&information among the different product, manufacturing and management domains is separated; 2) the demand of refined management and control with cost, efficiency, quality and safety as the core is prominent, but production, supply and marketing are disjointed which directly affects the production efficiency, energy consumption, material consumption and pollutant emission of non-ferrous metal smelting; 3 ) the non-ferrous metals products are stable in variety, and the demand for personalized customization is important for the downstream production enterprises, when the products themselves cannot be upgraded through networking or embedded artificial intelligence technology, an intelligent product service platform should be further built to provide the personalized services for the partners. These problems are related not only to the manufacturing system, but also to the production system and business model. In order to solve these problems systematically and comprehensively, we proposed a novel intelligent manufacturing mode with human-cyber-physical (HCP) collaboration and fusion from three aspects: 1) intelligent manufacturing 
system with HCP collaboration and fusion, 2) product service system based on ecosystem platform, and 3 ) sustainable business model, to realize the safe, efficient and green production for the non-ferrous metal smelting process.

With the development of industrial Internet, big data, artificial intelligence and other new generation information technologies (NGIT), an intelligent manufacturing mode with HCP collaboration and fusion become possible. In the current digital economy era, the deep integration and fusion between the nonferrous metal industry and the NGIT, such as the new generation artificial intelligence(Ahmad et al., 2021) (Haenlein and Kaplan, 2019)(Wu et al., 2020), internet of things (IOT) (Mosenia and Jha, 2017)(Sisinni et al., 2018), cloud computing(Varghese and Buyya, 2018)(Ren et al., 2019), big data(lqbal et al., 2020)(Cui et al., 2020), industrial internet, digital twin (Tao et al., 2018) and so on, provides a great opportunity for the non-ferrous metal industry to breed a new intelligent manufacturing mode with HCP collaboration and fusion, which can solve the above problems and bring new development opportunities to non-ferrous metals enterprises.

Combined with the development of information technology and the demand change of manufacturing mode, this paper discusses a novel intelligent manufacturing mode with HCP collaboration and fusion for the non-ferrous metal industry in detail. Section 2 discussed the proposed intelligent manufacturing mode with HCP collaboration and fusion in the non-ferrous metal industry; The manufacturing system, product and service system and business model in non-ferrous metal industry, which accommodated the proposed manufacturing mode, are discussed in section 3, 4 and 5 respectively; Next, a case study is depicted from the largest copper smelting enterprise in the world in section 6 , the intelligent manufacturing mode with HCP collaboration and fusion, manufacturing system architecture, product and service platform architecture and business model innovation (BMI) process are given to build a collaborative intelligent manufacturing platform system.

\section{An Intelligent Manufacturing Mode With Hcp Collaboration And Fusion In The Non-ferrous Metal Industry}

\subsection{Manufacturing mode model}

Paul G. Goebel and Yoram Koren mentioned in "global manufacturing revolution" (Koren, 2010)that "manufacturing mode is a revolutionary integrated production mode in response to changes in social and market demand." It is the form or operation mode of manufacturing enterprises in production and operation, management systems, organizational structures, and technical systems.

Manufacturing enterprises must respond quickly to consumers and markets anywhere in the world to maintain their global competitiveness. This response comes from three aspects (internal driving forces) as shown in Fig.1: the product system, manufacturing system, and business model. The integration of different manufacturing system, business model, and product system produces a different manufacturing mode to respond the market changes and the social needs. The external driving force of 
each new manufacturing mode is from market demand, social needs, and new enabling technologies, the new enabling technologies enable the manufacturing mode.

\subsection{The development of the manufacturing mode}

The digital, networked, and intelligent development of the manufacturing industry is an irreversible trend. As shown in Fig.2, the manufacturing paradigm has successively gone through mechanization, electrification, digital manufacturing, smart manufacturing, and intelligent manufacturing 2.0(Zhou et al., 2018). The enabling technologies of mechanization and electrification caused the first and the second industrial revolution, respectively. From the digital manufacturing and smart manufacturing to intelligent manufacturing 2.0, the enabling technologies are mainly from information technology. The development of information technologies has experienced a data processing era, PC era, internet era, mobile internet era, the current digital and intelligent economy era. The manufacturing mode is an instance of the different manufacturing paradigm. In general, the paradigm is abstract, and the mode is more specific or concrete. Each manufacturing paradigm has many kinds of different manufacturing mode, which is always related to the product development level, market demand and the enabling technologies at that time.

\section{Mechanization manufacturing paradigm}

The mechanized manufacturing paradigm mainly refers to the manual manufacturing mode. The characteristic of manual manufacturing is that individuals complete the design, processing, assembly, and inspection of products. Thus it is difficult to complete the large-size production of products.

\section{Electrification manufacturing paradigm}

The electrical manufacturing paradigm mainly refers to a large-scale manufacturing mode, also known as Ford mass production. Most workplaces are fixed, and a certain process for a part is processed according to a certain production rhythm for a long period. The production of high-quality standardized interchangeable parts is the main enabling technology for large-scale manufacturing success.

\section{Digital manufacturing paradigm}

The digital manufacturing paradigm includes some different manufacturing modes, such as lean manufacturing, flexible manufacturing, computer integrated manufacturing, agile manufacturing and contemporary integrated manufacturing accommodated to the enabling technologies, market demand and social needs at that time.

- Lean manufacturing

Lean manufacturing, also known as lean production in Japan, aims to produce high-quality products at a low cost. This means producing the required products according to the required quantity when needed to 
reduce manufacturing costs and improve product quality. Some management experts also call lean production "just in time".

- Flexible manufacturing and computer integrated manufacturing

The goal of flexible manufacturing in German and computer integrated manufacturing in USA is to produce a variety of small-batch parts and products at low cost through computer numerical control machine tools or robots.

- Agile manufacturing and contemporary integrated manufacturing

The goal of agile manufacturing and contemporary integrated manufacturing is to provide users with the required capabilities and services (personalized products and services) through product lifecycle data management.

The global manufacturing revolution began in the last decade of the 20th century. Globalization allows enterprises from different countries worldwide who produce similar products to join the ranks of competition, greatly intensifying worldwide competition. In this case, the personalized demand of consumers stimulates personalized production in the manufacturing market. At the end of the 20th century, global personalized production began to mature. Consumers can actively participate in the design process of purchasing products and accurately choose goods and services that meet their requirements by the agile manufacturing mode and contemporary integrated manufacturing mode.

\section{Smart manufacturing paradigm}

The smart manufacturing paradigm includes some different manufacturing modes, such as the American industrial Internet, Germany's Industry 4.0, and China's Internet plus.

With the proposal of national manufacturing strategies such as the industrial Internet of the United States in 2012(Aazam et al., 2018)(Boyes et al., 2018), German Industry 4.0(Beier et al., 2020)(Ghobakhloo, 2020) in 2013, and China's intelligent manufacturing 2025 in 2015, society has entered the smart manufacturing paradigm. Smart manufacturing is a digitally networked manufacturing paradigm. In essence, it is "Internet plus" manufacturing. It is based on digital manufacturing and networking, using the industrial internet and industrial cloud technology to realize universal communication and integration, and has certain intelligence.

The main features of internet plus manufacturing are as follows. First, in terms of products, digital technology and network technology are widely applied. Second, manufacturing realizes the connection and optimization of the supply chain and value chain between enterprises. This is obtained through the data flow and information flow of the whole manufacturing system. Third, in terms of service, enterprises and users realize connection and interaction through the network platform, enterprises grasp the personalized needs of users, and users can participate in the entire life cycle activity of a product, extending the industrial chain to provide services such as product health assurance for users. Mass 
customization has gradually become a common mode of development in the consumer goods manufacturing industry. The remote operation and maintenance service mode has been widely used in the construction machinery industry. Enterprise production began to transform from product-centered to user-centered, and enterprise forms also gradually transformed from production-oriented enterprises to production service-oriented enterprises.

With Cyber-Physical System as its core, German Industry 4.0 digitizes and integrates products, manufacturing, and services to realize integration and interconnection between enterprises. The United States' industrial Internet proposes integrating global industrial systems with advanced computing, analysis, sensing technology, and the internet to reconstruct global industry and stimulate productivity. Industry 4.0 of Germany and the industrial Internet of America have expounded and advanced the paradigm and technical route of digitally networked manufacturing.

China vigorously promotes "Internet plus" manufacturing. A number of enterprises are gradually transforming from internal interconnections to inter-enterprise interconnections while carrying out digital transformation by forming typical pilot projects. Haier Group has established an interconnected factory with an intelligent manufacturing execution system as the core, responding to the needs of global users in real-time and synchronously and quickly delivering intelligent and personalized solutions. Xi'an Aircraft Industry (Group) Co., Ltd. built the aircraft collaborative development and manufacturing cloud platform, realizing the collaborative development, dynamic analysis, and elastic allocation of manufacturing services and resources for 10 research units and more than 60 suppliers. The key to promoting smart manufacturing in China is promoting and applying large-scale Internet plus manufacturing in the next stage.

5. Intelligent manufacturing(2.0) paradigm

Digital manufacturing improves the efficiency and control performance of the production process. Smart manufacturing's industrial Internet mode adds product lines and extends the service capability of the product. Germany's Industry 4.0 improves the level of intelligent production processes. China's Internet plus mode will bring open, equality, interaction, and other network characteristics into the manufacturing industry, which will reshape the business model of manufacturing enterprises.

In the era of intelligent manufacturing 2.0, manufacturing systems will develop toward an intelligent manufacturing system with HCP collaboration and fusion. Products and services will be integrated to form an ecosystem service platform, and the traditional business model will be transformed into a sustainable business model.

\subsection{Intelligent manufacturing mode with HCP collaboration and fusion}

As shown in Fig.3, a new intelligent manufacturing mode with HCP collaboration and fusion in nonferrous metal industry is constructed. The new manufacturing mode includes three parts: product system based on ecosystem service platform, sustainable business model and intelligent manufacturing system 
with HCP collaboration and fusion. Sustainable business model consists of three parts: economy, environment and society; intelligent manufacturing system with HCP collaboration and fusion will have the ability of intelligent perception, analysis and decision-making, intelligent self-control and self-learning; product system will be an ecosystem service platform including product related services, process related services and other third-party services. The intelligent manufacturing system with HCP collaboration and fusion can improve the utilization rate of resources and energy, reduce the production cost of products and reduce environmental pollution. Ecosystem service platform can provide value-added services centered on customers. The sustainable business model examines the company's change towards sustainable development from three aspects of economy, environment and society.

\section{The Intelligent Manufacturing System With Hcp Collaboration And Fusion}

Although there are some differences between a traditional manufacturing system and an intelligent manufacturing system, their technical mechanisms are the same, and their essence is a HCP system. The traditional manufacturing system can be regarded as an HPS. The manufacturing system under digital manufacturing, smart manufacturing, and intelligent manufacturing 2.0 can be divided into HCPS1.0, HCPS1.5, and intelligent manufacturing system with HCP collaboration and fusion.

\subsection{HPS}

As shown in Fig. 4, in the traditional manufacturing system driven by HPS, the machine replaced humans to complete the manual labor portion. At this stage, the information system has not yet appeared, and it completely depends on the human to operate the machine to complete various tasks. Information perception, analysis, decision-making, cognitive learning, and other manufacturing system tasks are all completed by humans, with high requirements and high work intensity. The ability of manufacturing systems to deal with complex tasks is limited.

\subsection{HCPS1.0 and HCPS1.5}

Compared with the traditional manufacturing system, HCPS1.0 and HCPS1.5 introduced an information system. The information system can replace humans to complete part of the brain movement. Information perception, analysis, decision-making, cognitive learning, and other tasks need to be completed before being transferred to the information system. Computing and analysis, precision control, and the system's perception ability have all been greatly improved. As shown in Fig. 5, HCPS1.0 is characterized by the wide application of information technology such as computers, communication, and digital control, also known as digital manufacturing.

As shown in Fig. 6, the internet and cloud platforms are important components of the HCPS 1.5 manufacturing system. Information exchange and collaborative integration optimization become the main contents of this stage. 


\subsection{Intelligent manufacturing system with HCP collaboration and fusion}

In the prior manufacturing system, such as computer integrated manufacturing system and flexible manufacturing system, the human-cyber collaboratively make decision as followed: 1) humans endow knowledge to the cyber system, the cyber system works automatically under humans' will, has no self-learning ability and did not generate new knowledge; 2 ) the human-cyber system collaboratively participate in the decision-making process in which the cyber system acts as an executor.

Emerging information technologies such as IOT, big data, and artificial intelligence, have enabled HCP collaboration and fusion. The cyber system in the era of big data and artificial intelligence can not only complete part of human control, analysis, decision-making and perception functions, but also has a certain self-learning ability. Regardless of the stage of manufacturing system, humans always play the dominant role and are the creators of cyber and physical systems. Humans must grasp the highest decision-making and operation of the system. The role of humans does not change much when the cyber system changes.

In the intelligent manufacturing system with HCP collaboration and fusion, the cyber system can accumulate a large amount of data in the process of knowledge automation and can learn new knowledge from these data. At this time, a cyber system's role is similar to a collaborator to support decision-making because it can generate knowledge independently. Hence intelligent manufacturing system with HCP collaboration and fusion can be regarded as the real meaning of human-machine collaborative decision-making and fusion.

As shown in Fig. 7, the intelligent manufacturing system with HCP collaboration and fusion consists of three parts: 1) the human-machine interface (HMI) and equipment autonomous control system; 2) the digital twin based Human-Cyber collaborative analysis and decision-making system; 3 ) the knowledge graph based Human-Cyber-Physical data fusion system. The HMI \& equipment autonomous control system includes intelligent perception, intelligent analysis and decision-making, intelligent autonomous control, $\mathrm{HMI}$ and the physical system. The digital twin based Human-Cyber collaborative analysis and decision-making system consists of human-cyber collaborative learning promotion, accurate execution, independent decision-making and real-time analysis based on the digital twin and the new generation of Al. The knowledge graph based Human-Cyber-Physical data fusion system provides the fusion methods for the sensor data, product data, manufacturing data, management data and abstract data respectively from the physical system, cyber system and human.

1. the digital twin based Human-Cyber collaborative analysis and decision-making

Under the background of large-scale customization, flexible production, part tracking and product selfawareness of industry 4.0 and communication between machines and other products, field equipment, machines, factories and individual products will be connected to the network. As a key concept of industry 4.0, CPS can be described as a group of physical devices, objects and facilities that interact with virtual cyber space through communication network. Among them, each physical device takes its virtual 
cyber as the digital representation of its real device, and finally forms "digital twin". In cyber physical system, digital twin is like virtual representation of physical products, which is a digital image containing all information and knowledge. Through data transmission from physical part to network part, it can monitor and control physical entities, and physical entities can send data to update their virtual models. The digital twin model realizes the cooperation between human and cyber in intelligent manufacturing system. For example, the digital machine twin tool in the field of equipment management integrates manufacturing data and sensing data into digital twin model to improve the reliability and cooperation ability of CPS.

Therefore, a digital twin model in the nonferrous metal industry is constructed as shown in Fig.8. By constructing various twin models of information space, such as simulation, mechanism, prediction, evaluation, optimization and control, HCP coordination and iterative optimization in information space and physical space can be realized to integrate material flow, energy flow and information flow, and to improve the intelligent degree of manufacturing system.

The resource layer represents the bottom part of the stack. Resources include physical entities such as design and construction drawings, product process documents, raw materials, manufacturing equipment, production workshops and factories, as well as energy sources such as electricity and gas. Human can also be regarded as a part of resources. The resource layer represents the boundary of a large amount of data collection and control, and also represents the software and hardware adapters connected to the machine, which are necessary to communicate with the upper layer.

The link layer provides communication and data connection services, including cloud infrastructure, cloud services, cloud storage and network hardware.

The data layer represents the data communication with the resource layer. All kinds of resources from different domains, such as product, manufacturing and management, have their own virtualization state. This virtualization is supported by a database instance. The database instance is constructed to receive real-time stream data from resources. The driver written on this data layer can communicate with the exclusive interface of a single machine. The knowledge map of different domains in the data layer is used for data analysis and fusion, and the heterogeneous data of product, manufacturing, management and other subject domains is integrated to facilitate higher-level system call.

The model layer provides different model views of all kinds of resources, and provides resource location, status, simulation, mechanism, optimization evaluation, etc. to support collaborative optimization and decision-making of manufacturing system.

The function and service layer provides a variety of specific applications.

2. the knowledge graph based Human-Cyber-Physical data fusion

In the intelligent manufacturing system of non-ferrous metal industry, the data is from the products, production and management domains, in which the data storage structures are not the same. It is difficult 
to realize data sharing and fusion, and to mine the relationship between different domain data, and to support the cross layer and domain collaborative optimization of business process.

The multi domain data of manufacturing system can be divided into human-related data, cyber system related data and physical object related data. Among them, human (human resource) has the advantage of incomplete information based decision-making ability and the disadvantage of poor ability to acquire deep knowledge, cyber system has the advantage of processing massive data and the disadvantage of poor ability to process incomplete information, physics system has the advantage of strong execution ability and the disadvantage of lack of strong data processing ability. How to effectively integrate these three types of heterogeneous data, build enterprise data space, realize data cross domain interconnection, and improve the utilization rate of data are some urgent problems to be solved.

Knowledge graph is often used to fuse multi-source data, which can consider the association and characteristics between multi-source data. A knowledge graph based Human-Cyber-Physical data fusion framework is constructed to provide technical support for cross layer and domain collaborative optimization and decision-making, and data fusion. As shown in Fig. 9, there are three steps to build the knowledge graph: 1) human-cyber-physical object data acquisition; 2) human-cyber-physical knowledge extraction; 3) human-cyber-physical knowledge storage.

3. The human-machine \& human-cyber interface

In nonferrous metal industry enterprises, decision-makers of remote management realize human-cybermachine interaction through voice user interface, graphical user interface, dialogue user interface, touch interactive interface and three-dimensional interactive interface.

\section{The Product And Ecosystem Service Platform}

With the repaid development of information technologies, the product system has undergone profound changes. Digital technologies, such as IOT, internet, data analysis and artificial intelligence, enrich the functions of products, turn products into intelligent product and service system, and open up new markets. Intelligent product and service system has acquired increasing collaboration and response speeds and can be transformed into a product and ecosystem service platform. A product is a commodity for sale, and a platform is an infrastructure to support the interaction between different participants.

The transformation from simple passive products to intelligent product and ecosystem service platforms means that the equipment and software manufacturing industry has undergone structural changes. Successful service platforms will produce a network effect, and the value of the platform will be added with increases in the number of users and usage. With the participation of users, the "economies of scale of the supplier," which originally depended on expanding the scale of manufacturing, supply chain, procurement, and distribution, will be transformed into "economies of scale of the demander," which depends on the number and usage of users. 
Product manufacturers need new technologies and services to deliver the final services and maximize the value. To cooperate with multiple ecosystem partners, few companies can independently provide all the components, software, and services that match the hardware products. For example, the situation of Nikon (independent development) vs. ASML (Advanced Semiconductor Material Lithography) in the field of lithography, where the latter has achieved great success in the industry. Enterprises must integrate into each other's ecosystem or original products, integrate products into platform, ecosystem, or service solutions, and sell them in the form of a service.

\subsection{Change product structure from mechanical parts to digital accessories}

The change of the source of value creation requires manufacturers to transform their products fundamentally. Decades ago, the value source began to change, and the proportion of software in terms of product value was rising. It is expected that the speed of this transfer will move increasingly faster in the digital process. As shown in Fig. 10, at present, the distribution of product value sources is as follows: $40 \%$ software, $30 \%$ electronic devices, $20 \%$ mechanical parts, and $10 \%$ digital accessories. Digital accessories generally have the following artificial intelligence functions: machine learning, intelligent voice assistant user interfaces, natural language processing and collecting, processing, and analyzing large amounts of data. It is estimated that the future value sources are $20 \%$ software, $5 \%$ electronic devices, $5 \%$ mechanical parts, and $70 \%$ digital accessories, which are needed to carry on the fundamental transformation of the product.

As shown in Fig. 11, in the past, products were functional, and their structures included mechanical, electronic, and software parts. In the future, products will be experiential. In addition, there are data, services, user interfaces, and other parts that can allow the products to craft user-centered intelligent services.

\subsection{Integrating products and services into an ecosystem service platform}

Many products have a certain degree of intelligence, which greatly improves the user experience. When a product improves its intelligence, connectivity, and experience, user perceptions will also change. With the emergence of increasingly intelligent products, the economy dominated by product performance will gradually change to an economy dominated by experience. Experience is tailor-made for everyone and is based on the sum of all interactions between consumers or enterprise users and companies providing products, services, or brands, with a high degree of personalization. Therefore, the experience is more difficult to design than the product itself, which often requires the full participation of users.

As shown in Fig. 12, the vertical axis describes the product change process from focusing on the function to the service and experience. In the beginning, the company relied on value-added services to expand the production of products. These services can be basic services such as quality assurance and product support or more complex services such as data services based on internet products. In the process of changing to the "product as a service" model, which focuses on services rather than outputs, there has been a substantial change, that is, enterprise has changed from selling transactional products and 
services to marketing transactional products and services to design, sell and support an end-to-end user experience. Some companies will experience more significant change as they develop their products into a platform to connect with many ecosystem partners. Among them, customer experience and customer service should not be confused. Customer service is expected to help customers solve problems, submit complaints, provide feedback, or request certain content. The customer experience is more proactive and continuous. If the enterprise has reliable products and services, especially if it has a strong customer experience, it may not need too many customer service activities.

The horizontal axis reflects the development of product technology, from traditional product, internet product to autonomous product. Traditional products are connected to the network by adding sensors that generate and transmit data to form internet products or embedded in artificial intelligence to form smart or autonomous products. In this process, the product architecture and development process will undergo fundamental changes.

Traditional products and basic internet products: the vast majority of products need to be improved in their connectivity and user experience to enter the new value space.

Internet product as a service: it transforms from a transactional hardware sale model to an "as a service" business model. that is, the service mode can immediately improve the product experience.

Intelligent products: artificial intelligence technology is widely used into intelligent products either as an embedded function or is applied by the edge and cloud network.

Intelligent service: intelligent service combines intelligent product and service as a business model. With the advent of artificial intelligence, large-scale customized and personalized services will become a reality, which will improve the value for individual users or customers.

Ecosystem platform: an ecosystem platform will completely change the business model. Whether it is to build a platform or use a third-party platform to provide intelligent products or services, it can bring value creation.

\section{The Sustainable Business Model Innovation}

The new generation information technology promotes enterprises to change their production system and manufacturing system. These changes can reduce costs and increase efficiency for an enterprise which maintains its competitive advantage and seizes new opportunities. However, these changes cannot ignore the evolution of value creation. To better realize the transformation on the enterprise strategic level, we need to analyze this process from the perspective of business model innovation (BMI).

\subsection{Business model concept}

$\nabla 1 \otimes T h e$ definition of a business model 
For many years, the business model has been regarded as an indispensable tool in business activities, outlining the process of enterprise value creation. Although much research(Keiningham et al., 2020) (Laukkanen and Tura, 2020)(Savolainen and Collan, 2020) has been done on business models, the research in this field is still in its infancy. Thus far, there is no consistent definition for a business model. These studies use different terms to describe the elements of a business model, including market segmentation, value proposition, value chain structure, value acquisition mechanism, and the relationship between the elements(Saebi et al., 2017). Most business model definitions are consistent with Teece's: business model is "the design or architecture of the value creation, transmission, and acquisition mechanism it adopts"(Teece, 2010).

\section{\2\Business model canvas}

The business model canvas is the most commonly used form proposed by Alexander Osterwalder and Yves Pigneur(Osterwalder et al., 2010) to draw an enterprise business model. It is a common language used to describe, visualize, evaluate, and change a business model. As shown in Fig. 13, the business model canvas consists of nine basic building blocks, covering four aspects: customer, provision (product/service), infrastructure, and financial viability. It can easily describe and use the business model to build new strategic alternatives. The economic business model canvas aims to analyze the business model from an economic point of view.

As shown in Fig. 14 and Fig. 15, Joyce et al. (Joyce and Paquin, 2016)extended the business model canvas proposed by Osterwalder et al. by adding the social layer and the environmental layer, the social business model canvas is used to represent the relationship between stakeholders and enterprises, and the environmental business model canvas is used to represent the environmental benefits of enterprises and the impact of products on the environment in the whole life cycle. These three kinds of business model canvas are the tools for enterprises to change their business model for sustainable development.

\section{$5.2 \mathrm{BMI}$}

BMI is often referred to as a process designed to reduce costs(Wirtz et al., 2016), optimize processes, enter new markets or improve financial performance(Foss and Saebi, 2017). Compared with product and process innovation, $\mathrm{BMI}$ is a systematic change that affects the value proposition of enterprises and how value is generated. Some studies $(\mathrm{Li}, 2020)$ show that $\mathrm{BMI}$ is more successful than product or process innovation. Generally, enterprises with the best BM dominate the market rather than leading technology solutions(Chesbrough, 2010). The development of the BMI process is usually related to changes in the competitive environment or the emergence of new enabling technologies. New enabling technologies will have a subversive impact on their industry, resulting in new models, new ecology, and new development opportunities, bringing new pressure and challenges to enterprises. Generally, enterprises that seize the opportunity for transformation will achieve great success, while enterprises that ignore the change are easily surpassed and eliminated. 
At present, most of the research on the impact of new enabling technologies on business model change is about Industry 4.0, which was first proposed by Germany. It aims to use an IOT information system to digitize intelligent supply, manufacturing, and sales information in production and finally realize a fast and effective personalized product supply (Frank et al., 2019). Industry 4.0 can improve the production efficiency of enterprises. Optimizing the manufacturing system which can achieve the minimum resource and energy inputs while maximizing output and reducing costs in production, logistics, and quality management(Rojko, 2017). Industry 4.0 can also change the form of products, turning products into smart products(Ślusarczyk et al., 2019). It can connect with users and obtain users' data, providing personalized or customized services for users. In addition, users can actively participate in the product design process. Some studies summarize the types of BMI in manufacturing Industry 4.0. Dorleta(Ibarra et al., 2018) divides the BMI of enterprises through Industry 4.0 into incremental innovation and fundamental innovation. Incremental innovation includes internal and external process optimization and customer interface improvement, while fundamental innovation includes new ecosystem and value networks and intelligent products and services(Beverungen et al., 2019). From the perspective of value creation, these innovations can be summarized into two types. The first is that enterprises can optimize the production efficiency of the manufacturing system through new enabling technologies, provide the highest level of output with the lowest amount of resources, continuously optimize resource and energy consumption, reduce costs and increase efficiency, and obtain new values. The other is to provide customers with new services or products based on customer needs to create new value for customers.

Although BMI under Industry 4.0 has brought many benefits to enterprises, most of the enterprises studied belong to discrete industries. In contrast, non-ferrous metals enterprises belong to the process industry, which is very different from discrete industry. The demand for personalized customization of non-ferrous metals products is small, and the products cannot be upgraded to "intelligent products", which lacks high value-added services. Additionally, the production process of non-ferrous metals is long, and the utilization rate of resources and energy needs to be further improved. The waste in the production process has great damage to the environment, and the environmental protection issue is prominent. In order to make the non-ferrous metal industry develop efficiently and green and improve the competitiveness of the enterprises, it is necessary to study the sustainable business model of the nonferrous metals enterprises. HCP collaboration and fusion, as a new enabling technology, non-ferrous metals enterprises need to use it to seize the opportunity to achieve BMI.

\subsection{Sustainable business model in intelligent manufacturing mode}

The intelligent manufacturing mode with HCP collaboration and fusion will transform the manufacturing system and product system, improve the production efficiency of manufacturing system, reduce pollution emissions, and improve the added value of products. These sustainable development practices make enterprises develop towards green and efficient direction. From a strategic point of view, the connotation of green sustainable development needs to be reflected in the business model. As shown in Fig. 16, a BMI framework is built. 
The benchmark is the traditional business model of non-ferrous metals enterprises, which does not consider sustainability in value proposition. The manufacturing system of HCP collaboration and fusion and ecosystem service platform will bring sustainable development practice. The reformed sustainable business model represents the value proposition of green, efficient and sustainable development of enterprises.

Proposition 1 (P1). The traditional business model represents the value proposition of the enterprise in the past, without considering the green, efficient and sustainable.

Proposition 2 (P2). BMI is a process of internalizing the external changes of enterprise competitive environment from a strategic point of view, which changes the value proposition of enterprises.

Proposition 3 (P3). HCP collaboration and fusion enabling technology is an important external change factor in the competitive environment of enterprises, which can improve the production efficiency of enterprises and bring sustainable development practice.

Proposition 4 (P4). HCP collaboration and fusion driven practice in line with the theme of sustainable development, such as some measures to reduce pollution and improve production efficiency.

Proposition 5 (P5). The sustainable business model represents the new value proposition of the enterprise, integrates the connotation of sustainable development, and enables the enterprise to develop towards sustainable direction.

\section{Case Study In The Non-ferrous Metal Industry}

The case study is based on the Jiangxi Copper Group, founded in July 1979. Jiangxi Copper Group is a large-scale joint enterprise in China's non-ferrous metal industry that integrates copper mining, beneficiation, metallurgy, and processing. It is the largest production base of copper products and an important source of sulfur chemical raw materials, gold, silver, and rare metals. The company is headquartered in Nanchang, Jiangxi Province, China. Jiangxi Copper Group owns the first copper smelting enterprise with a flash furnace in China as well as the largest single copper processing plant in the world, and it is the largest copper and gold producer in China. Jiangxi Copper Group includes these firms: Guixi Smelter; Jiangxi copper (Qingyuan) Co., Ltd; Zhejiang Jiangtong Fuye Heding Copper Co., Ltd. These companies combine for an annual output of 1.4-1.5 million tons of copper, 30 tons of gold, and 400 tons of silver.

To realize the safe, efficient and green production for the coper metal smelting process, we constructed the intelligent manufacturing mode with HCP collaboration and fusion from three aspects: 1) intelligent manufacturing system with HCP collaboration and fusion, 2) product \& ecosystem service platform, and 3) sustainable business model.

\subsection{Intelligent Manufacturing system with HCP collaboration and fusion}


As shown in Fig. 17, the intelligent manufacturing system with HCP collaboration and fusion in the nonferrous metal enterprise covers multiple production bases, multiple production lines, and multiple processes.

It encompasses the functions of supply chain management, production scheduling, quality control, logistics, and decision-making. The system comprises an HMI \&equipment autonomous control system, the digital twin based remote management analysis and collaborative decision system and the knowledge graph based HCP data fusion system. The equipment autonomous control system has the functions of intelligent perception, intelligent analysis and decision-making, and autonomous control. The digital twin based remote management analysis and collaborative decision system supports the cross layer-domain optimal control of key process, joint optimization of predictive maintenance and production scheduling, integration plan of production, supply and market. The knowledge graph based HCP data fusion system provides data and information fusion components to support HCP integration in the cross layer-domain optimal control, predictive operation and integrated plan. Fig.18 describes a domain knowledge graph for flash furnace production process, which depicts all entities and their relationships.

Compared with the traditional manufacturing system, the intelligent manufacturing system with HCP collaboration and fusion can optimize the whole process of copper smelting. When market demands or raw materials change, the whole process control of raw material procurement, business decision-making, planning and scheduling, process parameter selection, and production can achieve collaborative

optimization to optimize the overall operation of the enterprise, reduce costs, and improve efficiency with the goal of high efficiency, controllable safety, and environmental protection.

The mechanism model is a kind of digital twin and become the key to the HCP collaboration. Taking the flash furnace as an example, the real-time prediction of matte temperature, matte grade and iron silicon ratio in slag can be realized by establishing the mechanism and data model. On this basis, the process parameters of the control flash furnace process can be optimized, figure 19 shows the flash furnace melting model.

\subsection{Product \& ecosystem service platform}

As shown in Fig. 20, the participants of product \& ecosystem service platform for Jiangxi Copper group include enterprises, customers and partners. Partners are the main body that can provide services for customers outside the enterprises. The platform business includes four parts, namely non-ferrous metals products, product-related services, process-related services, and other services. Non-ferrous metals products are the traditional business of enterprises, including main products and subsidiary products. Other businesses of the platform are service-related, and these services can bring value to customers.

Product-related service is a supplement to product sales. The copper itself is traded as a good, so it is a common demand for customers to forecast its price. Enterprises can also provide product-related consulting services based on product experience. 
Process-related services are built on the basis of the internal processes of enterprises, and enterprises provide external consulting services, such as intelligent production and digital transformation.

Other services include some customized services or subscription services, which are provided based on the needs of customers.

\subsection{Sustainable business model}

\section{Q1षTraditional business model}

The economic business model canvas of Jiangxi copper group before the reform is shown in Fig. 21. The company's main partners are energy and resource suppliers, including raw material suppliers, power suppliers and equipment and machinery suppliers. In addition to these suppliers supporting production, other partners also provide IT solutions, logistics services and financial services. The company's main activities include procurement, marketing related business activities and production process related process planning, smelting processing and equipment operation and maintenance. There are some problems, such as the disconnection of production, supply and marketing, the low degree of intelligent production process, heavy pollution and high failure rate of production equipment. Mining, smelting technology and financial assets are the main resources of the company. The company's value proposition is to provide cost-effective non-ferrous metals products. The company's customers are mainly distributed in deep processing industries such as wire materials and pipes, and application industries such as electric power and household appliances. The company's income mainly depends on product sales and product processing. Non-ferrous metals products have serious homogenization and low added value. The company relies on large-scale production to maintain low-cost competitive advantage.

\section{\2囚Sustainable business model}

\section{- Economic business model canvas}

The economic business model canvas of Jiangxi copper group after the reform is shown in Fig. 22. The company's main partners have added third-party service providers. The company's ecosystem service platform can attract third-party service providers to settle in. The company and the third party jointly provide customer-centric services, and the service demand side can cover the company's upstream and downstream. In terms of main activities, due to the introduction of HCP collaboration and fusion enabling technology, production, supply and marketing activities can be integrated optimization and decisionmaking. The main process can be optimized across layers and equipment can be predictive maintenance and management, which can reduce production costs and improve production efficiency. In terms of main resources, an ecosystem service platform has been added. The value proposition part adds customer-centric services. The third party service provider of the platform is a partnership with the company. The company's revenue will not be limited to the sales and processing fees of non-ferrous 
metals products, and the ecosystem service platform will bring service fees and commission income to the company.

\2囚Sustainable business model

- Economic business model canvas

The economic business model canvas of Jiangxi copper group after the reform is shown in Fig. 22. The company's main partners have added third-party service providers. The company's ecosystem service platform can attract third-party service providers to settle in. The company and the third party jointly provide customer-centric services, and the service demand side can cover the company's upstream and downstream. In terms of main activities, due to the introduction of HCP collaboration and fusion enabling technology, production, supply and marketing activities can be integrated optimization and decisionmaking. The main process can be optimized across layers and equipment can be predictive maintenance and management, which can reduce production costs and improve production efficiency. In terms of main resources, an ecosystem service platform has been added. The value proposition part adds customer-centric services. The third party service provider of the platform is a partnership with the company. The company's revenue will not be limited to the sales and processing fees of non-ferrous metals products, and the ecosystem service platform will bring service fees and commission income to the company.

Acid production from flue gas: the largest acid production plant from smelting flue gas in China has been built, with total sulfur utilization rate of more than $97 \%$, reaching the top level in the world.

Copper extraction from wastewater: more than 1000 tons of copper are recovered from wastewater every year, and more than 20000 tons of wastewater are purified and treated every day.

Copper separation from slag: make full use of resources in smelting slag and recover valuable elements. More than 9000 tons of copper metals are recovered from smelting slag every year, which is equivalent to the annual metals output of a medium-sized copper mine in China.

- Social business model canvas

The canvas of social business model after the reform of Jiangxi Copper Group is shown in Fig. 24. The purpose of this canvas model is to investigate the interaction between the company's stakeholders and the company, and to capture the social impact of these key relationships.

The social value generated by the company includes providing high-quality products for customers, continuously excavating the value of resources and pursuing the harmonious coexistence of human and nature. The manufacturing system of HCP collaboration and fusion can bring high-quality, environmental protection and cost-effective products, and the ecosystem service platform can create more employment opportunities and increase local fiscal revenue. 


\section{Conclusion And Future Work}

Given the existing problems of the non-ferrous metal industry and the development of information enabling technology, this paper discusses the demand for transforming the non-ferrous metal industry's manufacturing mode. A new manufacturing mode of non-ferrous metal industry in the era of intelligent manufacturing 2.0 is put forward, which is the intelligent manufacturing mode with HCP collaboration and confusion. It includes intelligent manufacturing system based on HCP collaboration and confusion, product system based on ecosystem service platform, and sustainable business model. The intelligent manufacturing system with HCP collaboration and confusion can improve production efficiency and reduce environmental pollution. Product service system can provide customer-centered service, and sustainable business model can qualitatively and quantitatively describe the sustainable change process of manufacturing system and product system. The new manufacturing mode can make non-ferrous metals enterprises develop towards green, efficient and sustainable direction. Finally, combined with the largest copper smelting enterprise in the world (Jiangxi copper), the corresponding manufacturing system, product system and business model under the new manufacturing mode are given respectively.

The research of this paper is based on the case of non-ferrous metals enterprises. Next, we are going to use the new manufacturing mode proposed in this paper to study other manufacturing enterprises.

\section{Declarations}

\section{Acknowledgements:}

This work was supported partly by the National Key R\&D Program of China under 2019YFB1704700, partly by the Natural Science Foundation of China under 71690234.

\section{Author contribution:}

Qing Liu: Writing-original draft, writing-review and editing, investigation, methodology, experiments conduction

Min Liu: Writing-review and editing, project administration, methodology

Zichun Wang: Investigation, software development, visualization, data analysis, validation of the software tools

Feng Yan: Experiments conduction

Yingyi Ma: Experiments conduction

Weiming Shen: Writing-review, supervision

Data availability: Data sharing is not applicable to this article. 
Code availability: Code availability is applicable by the website on http://61.149.254.174:3889/login (uid:ysy/psw:111111).

\section{Declarations:}

Ethics approval Not applicable.

Consent to participate Not applicable.

Consent for publication Not applicable.

Competing Interests The authors declare no competing interests

\section{References}

Aazam, M., Zeadally, S., Harras, K.A., 2018. Deploying Fog Computing in Industrial Internet of Things and Industry 4.0. IEEE Trans. Ind. Informatics. https://doi.org/10.1109/TII.2018.2855198

Ahmad, T., Zhang, D., Huang, C., Zhang, H., Dai, N., Song, Y., Chen, H., 2021. Artificial intelligence in sustainable energy industry: Status Quo, challenges and opportunities. J. Clean. Prod. https://doi.org/10.1016/j.jclepro.2021.125834

Beier, G., Ullrich, A., Niehoff, S., Reißig, M., Habich, M., 2020. Industry 4.0: How it is defined from a sociotechnical perspective and how much sustainability it includes - A literature review. J. Clean. Prod. https://doi.org/10.1016/j.jclepro.2020.120856

Beverungen, D., Müller, O., Matzner, M., Mendling, J., vom Brocke, J., 2019. Conceptualizing smart service systems. Electron. Mark. 29, 7-18. https://doi.org/10.1007/s12525-017-0270-5

Boyes, H., Hallaq, B., Cunningham, J., Watson, T., 2018. The industrial internet of things (IloT): An analysis framework. Comput. Ind. https://doi.org/10.1016/j.compind.2018.04.015

Chesbrough, H., 2010. Business model innovation: Opportunities and barriers. Long Range Plann. 43, 354-363. https://doi.org/10.1016/j.Irp.2009.07.010

Cui, Y., Kara, S., Chan, K.C., 2020. Manufacturing big data ecosystem: A systematic literature review. Robot. Comput. Integr. Manuf. https://doi.org/10.1016/j.rcim.2019.101861

Foss, N.J., Saebi, T., 2017. Fifteen Years of Research on Business Model Innovation. J. Manage. https://doi.org/10.1177/0149206316675927

Frank, A.G., Dalenogare, L.S., Ayala, N.F., 2019. Industry 4.0 technologies: Implementation patterns in manufacturing companies. Int. J. Prod. Econ. 210, 15-26. https://doi.org/10.1016/j.ijpe.2019.01.004 
Ghobakhloo, M., 2020. Industry 4.0, digitization, and opportunities for sustainability. J. Clean. Prod. 252, 119869. https://doi.org/10.1016/j.jclepro.2019.119869

Haenlein, M., Kaplan, A., 2019. A brief history of artificial intelligence: On the past, present, and future of artificial intelligence. Calif. Manage. Rev. https://doi.org/10.1177/0008125619864925

Ibarra, D., Ganzarain, J., Igartua, J.I., 2018. Business model innovation through Industry 4.0: A review. Procedia Manuf. 22, 4-10. https://doi.org/10.1016/j.promfg.2018.03.002

Iqbal, R., Doctor, F., More, B., Mahmud, S., Yousuf, U., 2020. Big data analytics: Computational intelligence techniques and application areas. Technol. Forecast. Soc. Change.

https://doi.org/10.1016/j.techfore.2018.03.024

Joyce, A., Paquin, R.L., 2016. The triple layered business model canvas: A tool to design more sustainable business models. J. Clean. Prod. 135, 1474-1486. https://doi.org/10.1016/j.jclepro.2016.06.067

Keiningham, T., Aksoy, L., Bruce, H.L., Cadet, F., Clennell, N., Hodgkinson, I.R., Kearney, T., 2020. Customer experience driven business model innovation. J. Bus. Res. https://doi.org/10.1016/j.jbusres.2019.08.003

Koren, Y., 2010. The Global Manufacturing Revolution, The Global Manufacturing Revolution. https://doi.org/10.1002/9780470618813

Laukkanen, M., Tura, N., 2020. The potential of sharing economy business models for sustainable value creation. J. Clean. Prod. https://doi.org/10.1016/j.jclepro.2020.120004

Li, F., 2020. The digital transformation of business models in the creative industries: A holistic framework and emerging trends. Technovation 92-93, 102012. https://doi.org/10.1016/j.technovation.2017.12.004

Mosenia, A., Jha, N.K., 2017. A comprehensive study of security of internet-of-things. IEEE Trans. Emerg. Top. Comput. https://doi.org/10.1109/TETC.2016.2606384

Osterwalder, A., Pigneur, Y., Smith, A., Movement, T., 2010. Bussiness model Generation, Booksgooglecom. https://doi.org/10.1523/JNEUROSCI.0307-10.2010

Ren, J., Yu, G., He, Y., Li, G.Y., 2019. Collaborative Cloud and Edge Computing for Latency Minimization. IEEE Trans. Veh. Technol. https://doi.org/10.1109/TVT.2019.2904244

Rojko, A., 2017. Industry 4.0 concept: Background and overview. Int. J. Interact. Mob. Technol. https://doi.org/10.3991/ijim.v11i5.7072

Saebi, T., Lien, L., Foss, N.J., 2017. What Drives Business Model Adaptation? The Impact of Opportunities, Threats and Strategic Orientation. Long Range Plann. https://doi.org/10.1016/j.Irp.2016.06.006

Savolainen, J., Collan, M., 2020. How Additive Manufacturing Technology Changes Business Models? Review of Literature. Addit. Manuf. https://doi.org/10.1016/j.addma.2020.101070 
Sisinni, E., Saifullah, A., Han, S., Jennehag, U., Gidlund, M., 2018. Industrial internet of things: Challenges, opportunities, and directions. IEEE Trans. Ind. Informatics. https://doi.org/10.1109/TII.2018.2852491

Ślusarczyk, B., Haseeb, M., Hussain, H.I., 2019. Fourth industrial revolution: A way forward to attain better performance in the textile industry. Eng. Manag. Prod. Serv. https://doi.org/10.2478/emj-2019-0011

Tao, F., Cheng, J., Qi, Q., Zhang, M., Zhang, H., Sui, F. Digital twin-driven product design, manufacturing and service with big data. The International Journal of Advanced Manufacturing Technology, 2018, (94), pages: $3563-3576$

Teece, D.J., 2010. Business models, business strategy and innovation. Long Range Plann. 43, 172-194. https://doi.org/10.1016/j.Irp.2009.07.003

Varghese, B., Buyya, R., 2018. Next generation cloud computing: New trends and research directions. Futur. Gener. Comput. Syst. https://doi.org/10.1016/j.future.2017.09.020

Wirtz, B.W., Pistoia, A., Ullrich, S., Göttel, V., 2016. Business Models: Origin, Development and Future Research Perspectives. Long Range Plann. https://doi.org/10.1016/j.Irp.2015.04.001

Wu, F., Lu, C., Zhu, M., Chen, H., Zhu, J., Yu, K., Li, L., Li, M., Chen, Q., Li, X., Cao, X., Wang, Z., Zha, Z., Zhuang, Y., Pan, Y., 2020. Towards a new generation of artificial intelligence in China. Nat. Mach. Intell. 2, 312-316. https://doi.org/10.1038/s42256-020-0183-4

Yuan, X., Gui, W., Chen, X., Huang, K., Yang, C., 2018. Transforming and Upgrading Nonferrous Metal Industry with Artificial Intelligence. Chinese J. Eng. Sci. 20, 59. https://doi.org/10.15302/j-sscae2018.04.010

Zhou, J., Li, P., Zhou, Y., Wang, B., Zang, J., Meng, L., 2018. Toward New-Generation Intelligent Manufacturing. Engineering 4, 11-20. https://doi.org/10.1016/j.eng.2018.01.002

\section{Figures}




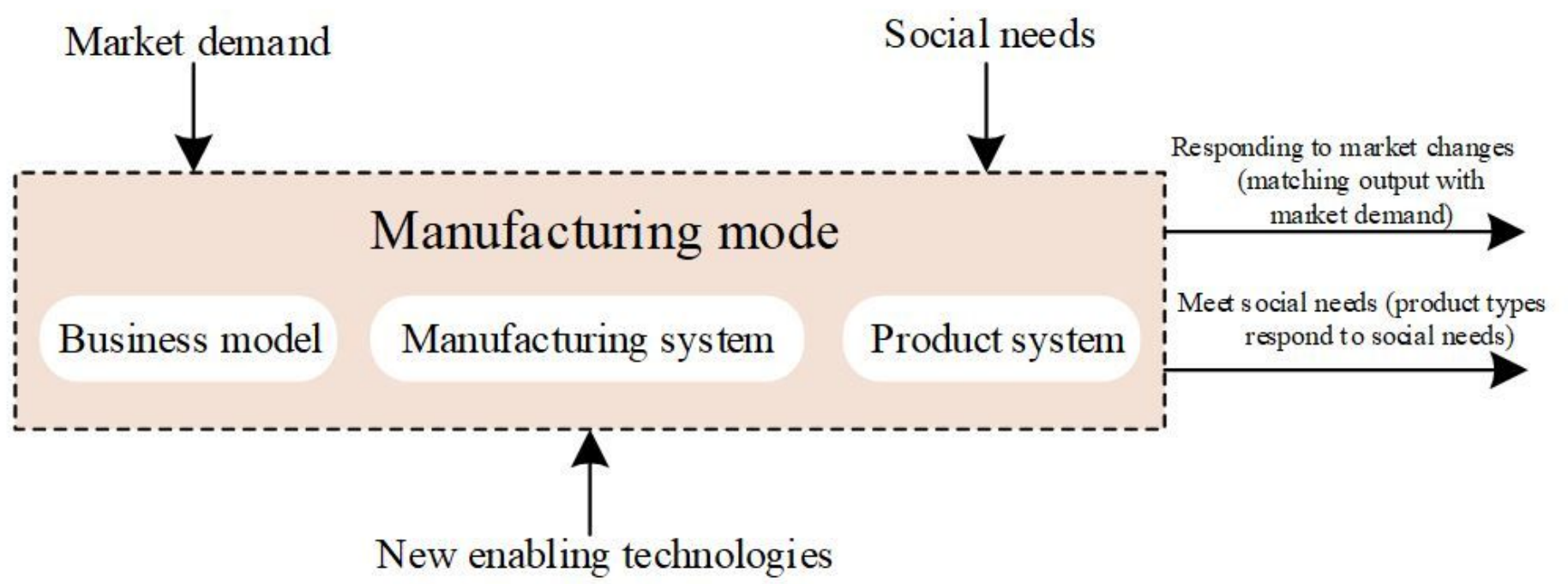

\section{Figure 1}

Manufacturing mode model

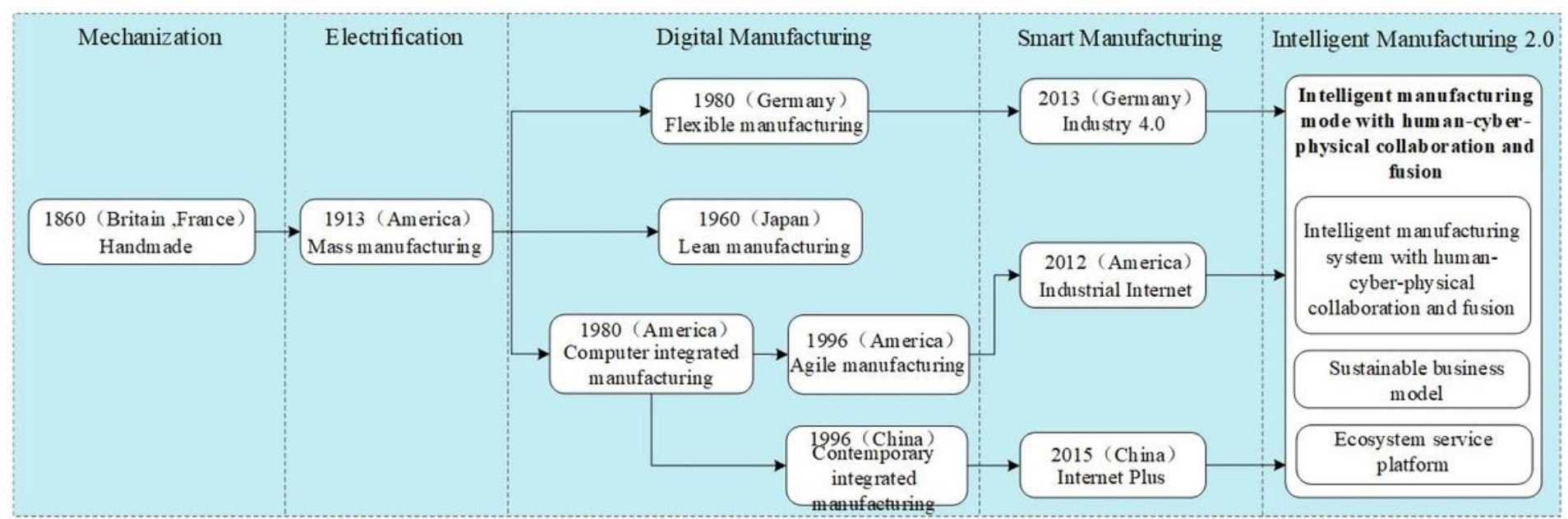

\section{Figure 2}

Development of manufacturing mode 


\section{Intelligent manufacturing mode with $\mathrm{HCP}$ collaboration and fusion}

\section{Ecosystem service platform}

Product related services: use product experience to provide advice and consultation, and provide product based derivative services

Process related services: provide consulting services based on internal process experience

Other services: use the platform to provide third-party services

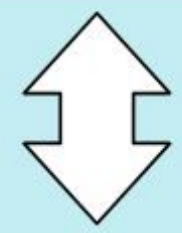

\section{Intelligent manufacturing system with HCP collaboration and fusion}

Intelligent autonomous control: strategy self adjustment and self perfection

Intelligent analysis and decision making: model self adjustment and self perfection

Intelligent perception: ubiquitous perception (real-time, multi-source, heterogeneous and dynamic)

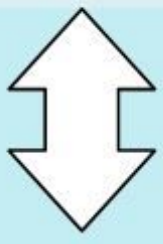

\section{Sustainable business model}

\section{Economic aspects}

1) Provide cost-effective non-ferrous metal products

2) Provide customercentric service
Environmental aspects

1) Energy saving and environmental protection

2) Circular economy

\section{Social aspects}

1) Create employment opportunities

2) Increase local revenue

3) Tap the value of resources

Figure 3

Intelligent manufacturing mode with HCP collaboration and fusion in non-ferrous metal industry 


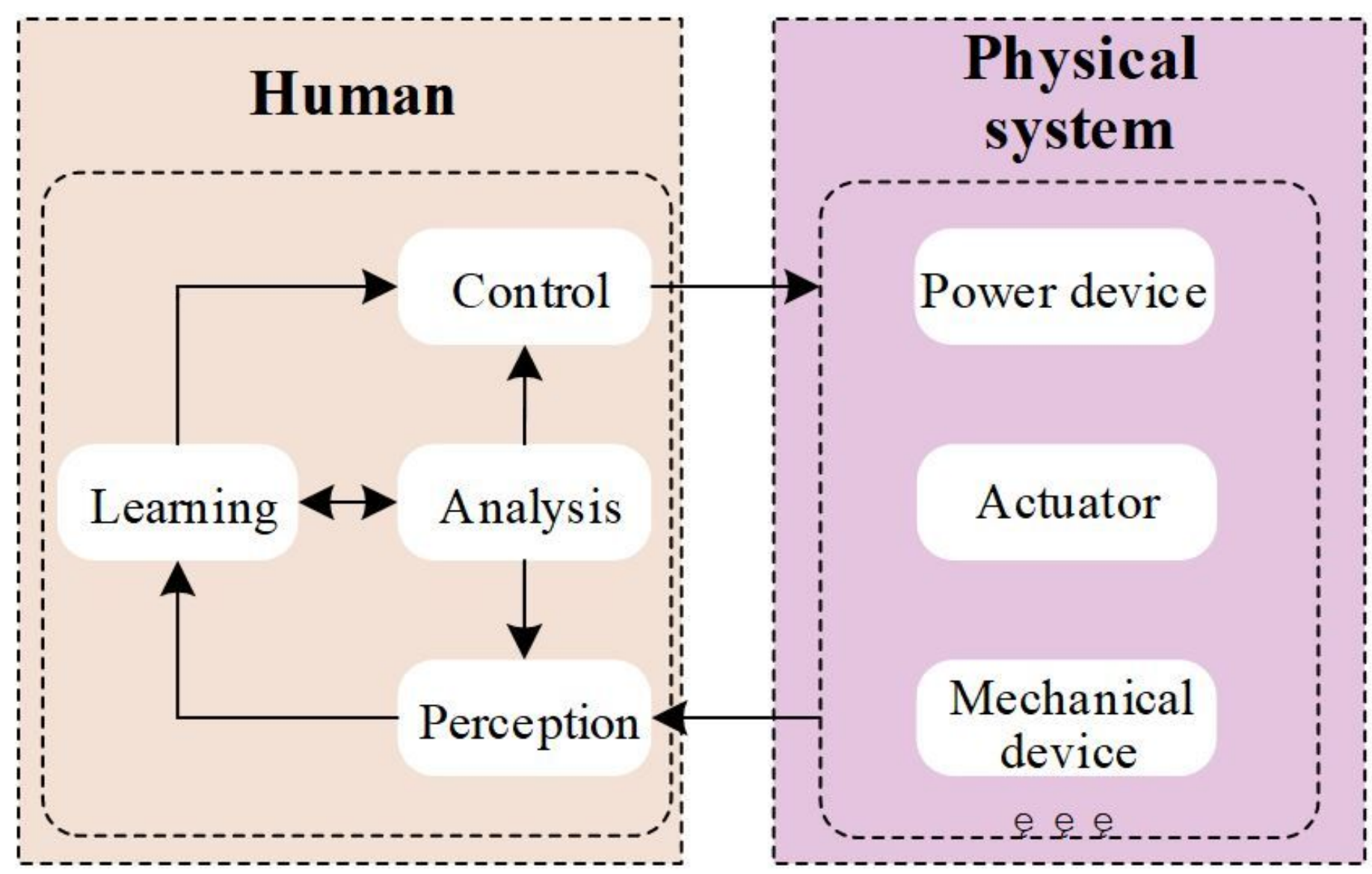

Figure 4

HPS driven manufacturing system

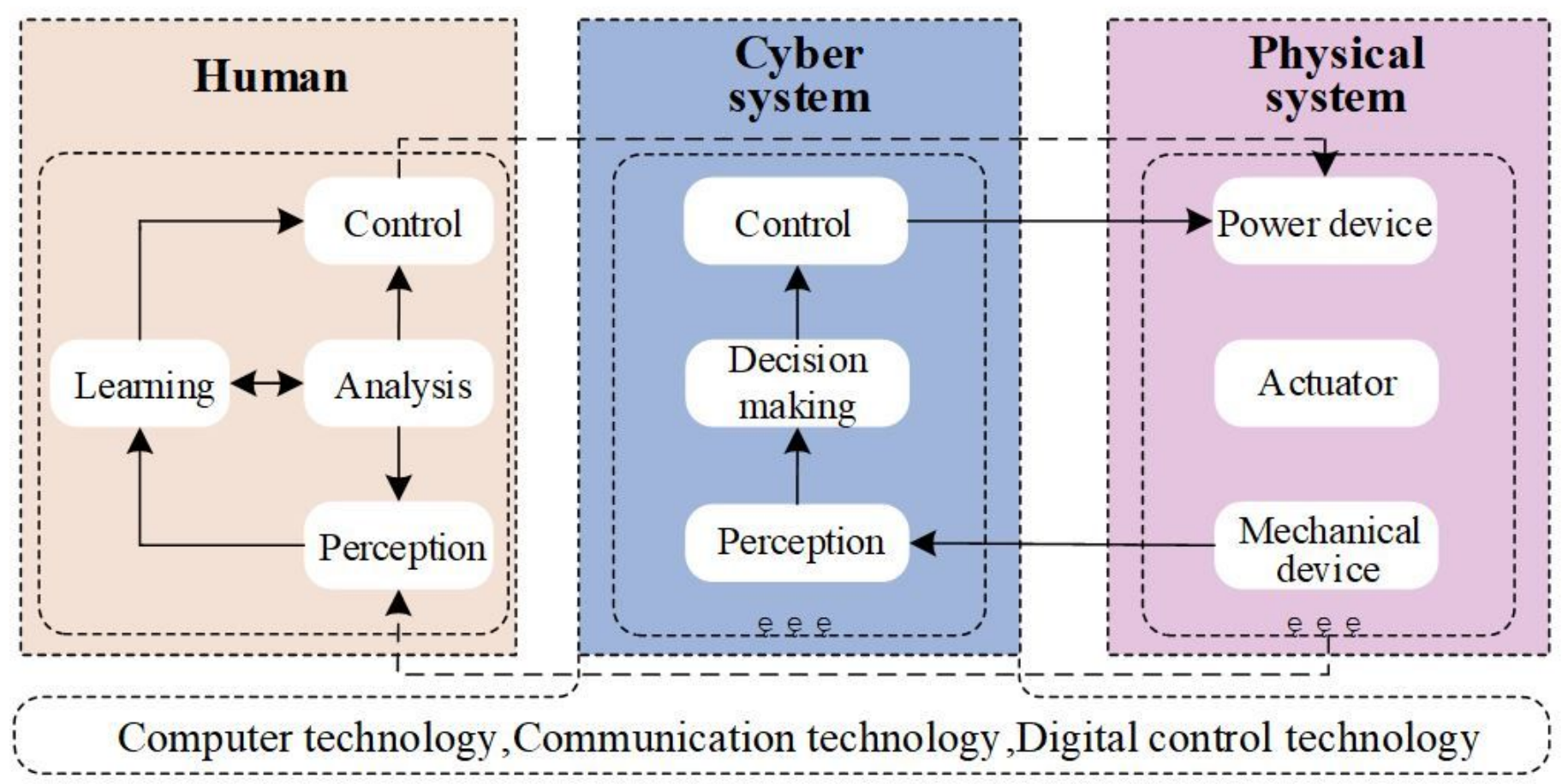

Figure 5 


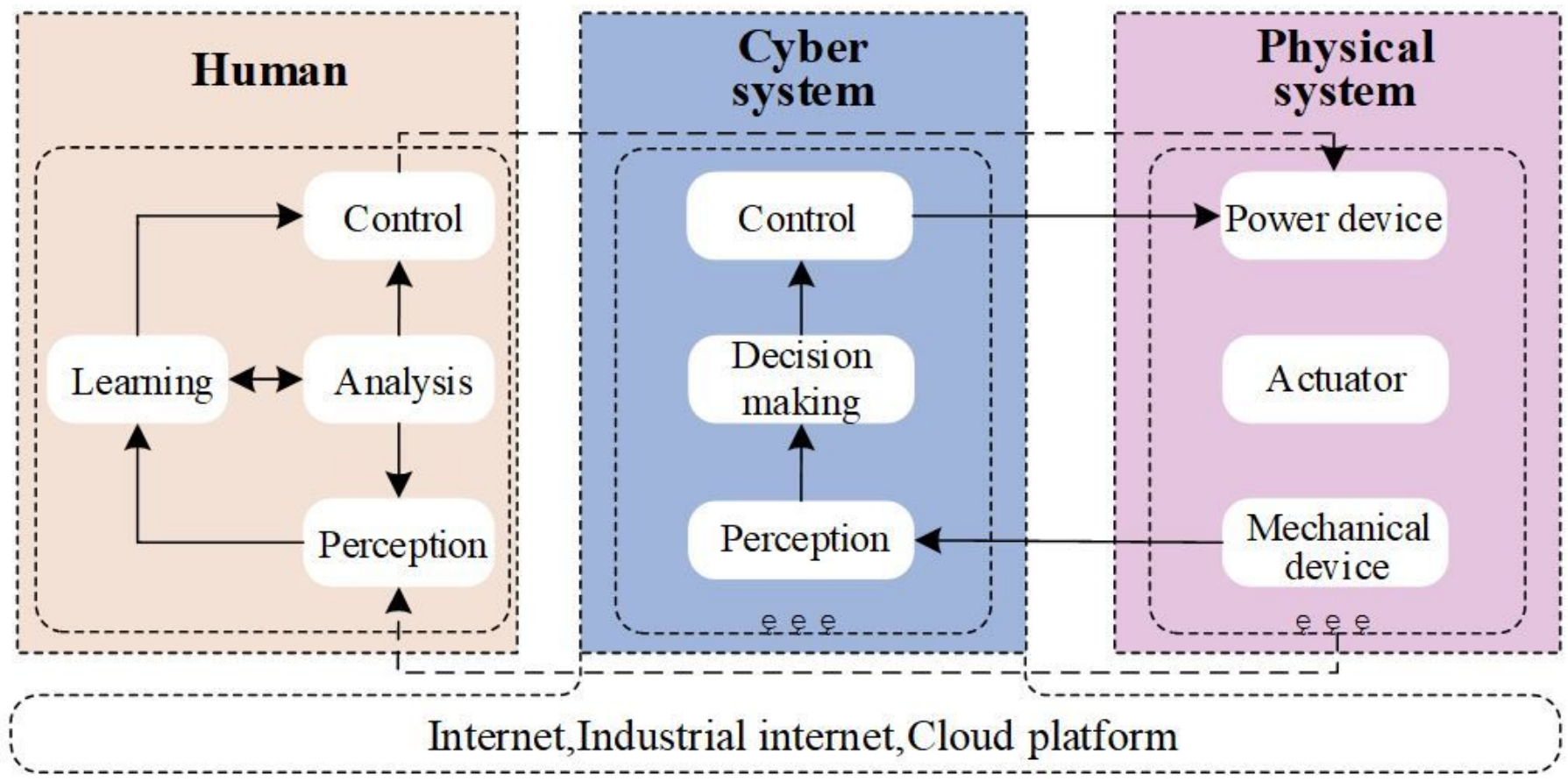

\section{Figure 6}

Manufacturing system driven by HCPS 1.5

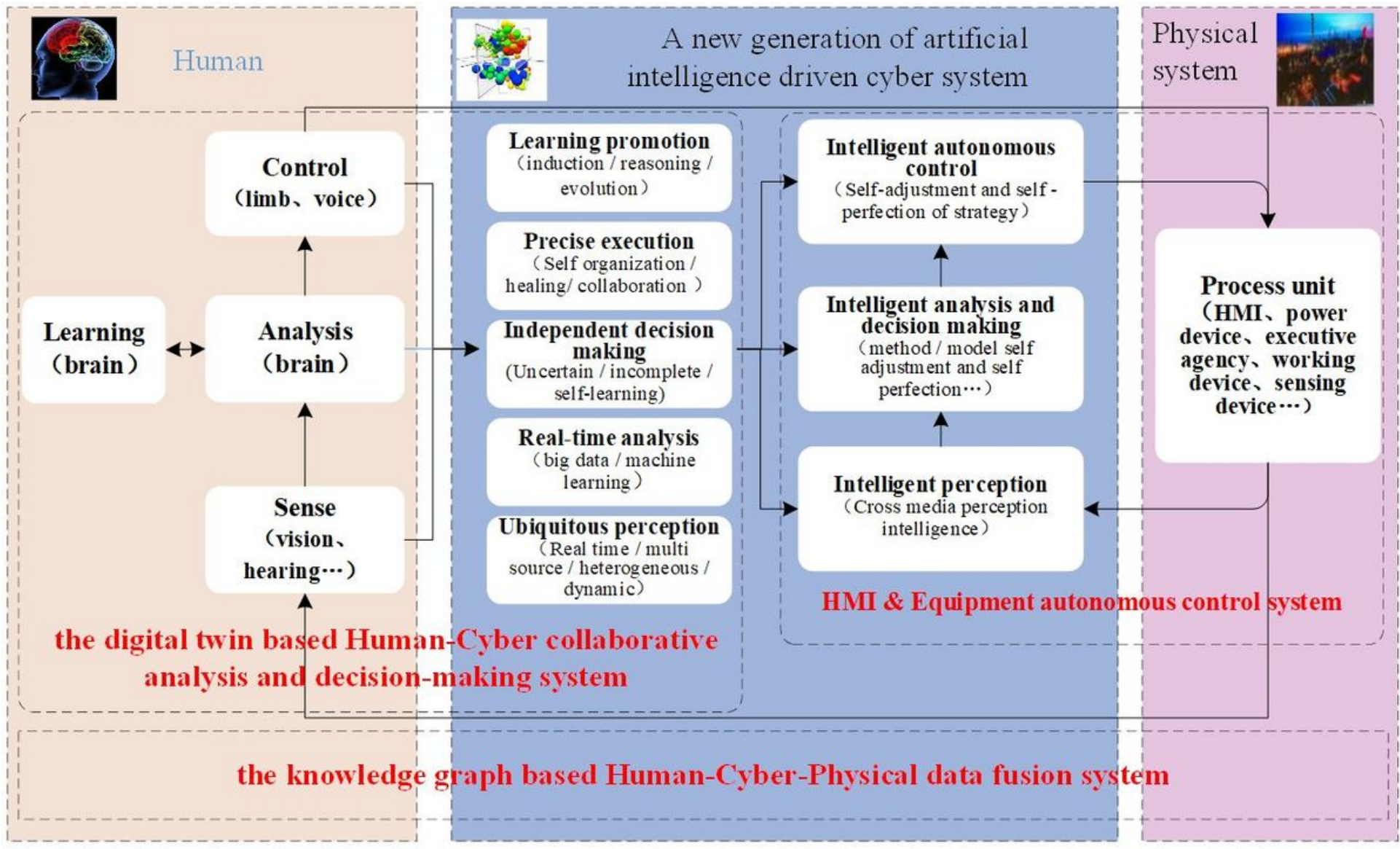


Architecture of the intelligent manufacturing system with HCP collaboration and fusion

\begin{tabular}{|c|c|c|c|c|c|c|c|c|c|c|}
\hline \multirow{8}{*}{ 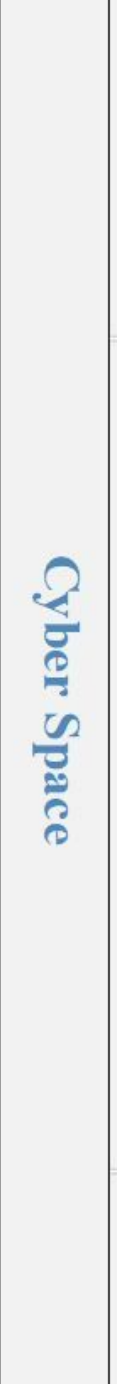 } & \multirow[t]{2}{*}{ SaaS } & \multirow{2}{*}{ 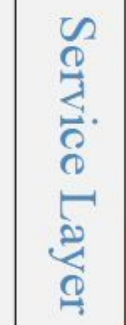 } & \multicolumn{2}{|c|}{ Service Driver } & \multicolumn{2}{|c|}{ APP } & \multicolumn{2}{|c|}{ APP } & \multicolumn{2}{|c|}{ APP } \\
\hline & & & \multicolumn{6}{|c|}{ Workflow management and service configuration } & \multicolumn{2}{|c|}{ Service Driver } \\
\hline & & $\begin{array}{l}3 \\
2 \\
2 \\
\frac{2}{0} \\
2 \\
2\end{array}$ & 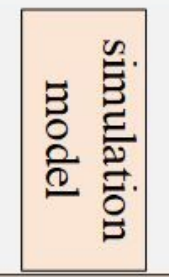 & 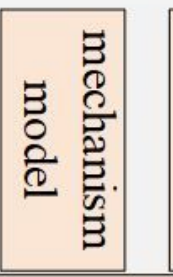 & 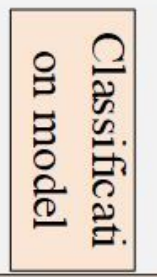 & 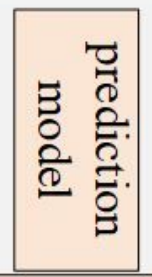 & 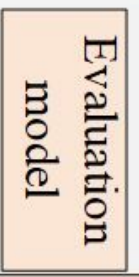 & 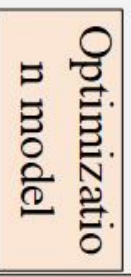 & $\cdots$ & 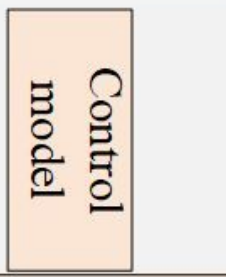 \\
\hline & & 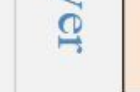 & \multicolumn{8}{|c|}{ Geometric model, position model and status model } \\
\hline & & & \multicolumn{8}{|c|}{ Product, Manufacturing and Management oriented Knowledge Graph } \\
\hline & & 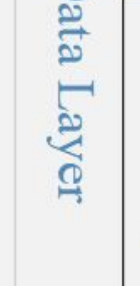 & \multicolumn{2}{|c|}{$\begin{array}{c}\text { Resource and } \\
\text { Management data } \\
\text { Material, formula, } \\
\text { market, supplier, etc }\end{array}$} & \multicolumn{4}{|c|}{$\begin{array}{l}\text { Manufacturing data } \\
\text { Air, oil, oxygen, status } \\
\text { parameters (pressure, } \\
\text { temperature, flow, speed, } \\
\text { vibration, etc.), commands, etc }\end{array}$} & \multicolumn{2}{|c|}{$\begin{array}{c}\text { Sensing data } \\
\text { Current, vibration, } \\
\text { dynamometer, speed, } \\
\text { AE signal / X } \\
\text { detection, video, etc }\end{array}$} \\
\hline & \multirow{2}{*}{ IaaS } & \multirow{2}{*}{ 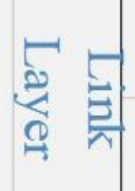 } & \multicolumn{8}{|c|}{ Cloud infrastructure (server, storage, network virtualization) } \\
\hline & & & \multicolumn{8}{|c|}{ Cloud service / cloud storage / network hardware } \\
\hline \multirow{2}{*}{ 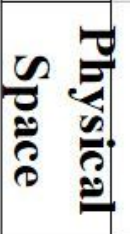 } & \multirow{2}{*}{ Edge } & \multirow{2}{*}{$\begin{array}{ll} & 7 \\
- & 0 \\
2 & 0 \\
2 & 0 \\
0 & \vdots \\
9 & 0 \\
& 0\end{array}$} & \multicolumn{8}{|c|}{$\begin{array}{l}\text { Edge computing / resource feedback / resource optimization / human } \\
\text { machine interface }\end{array}$} \\
\hline & & & \multicolumn{8}{|c|}{$\begin{array}{c}\text { Resource ontology / sensor system / servo execution system / protocol } \\
\text { analysis }\end{array}$} \\
\hline
\end{tabular}

Figure 8

Digital twin model for nonferrous metal industry 


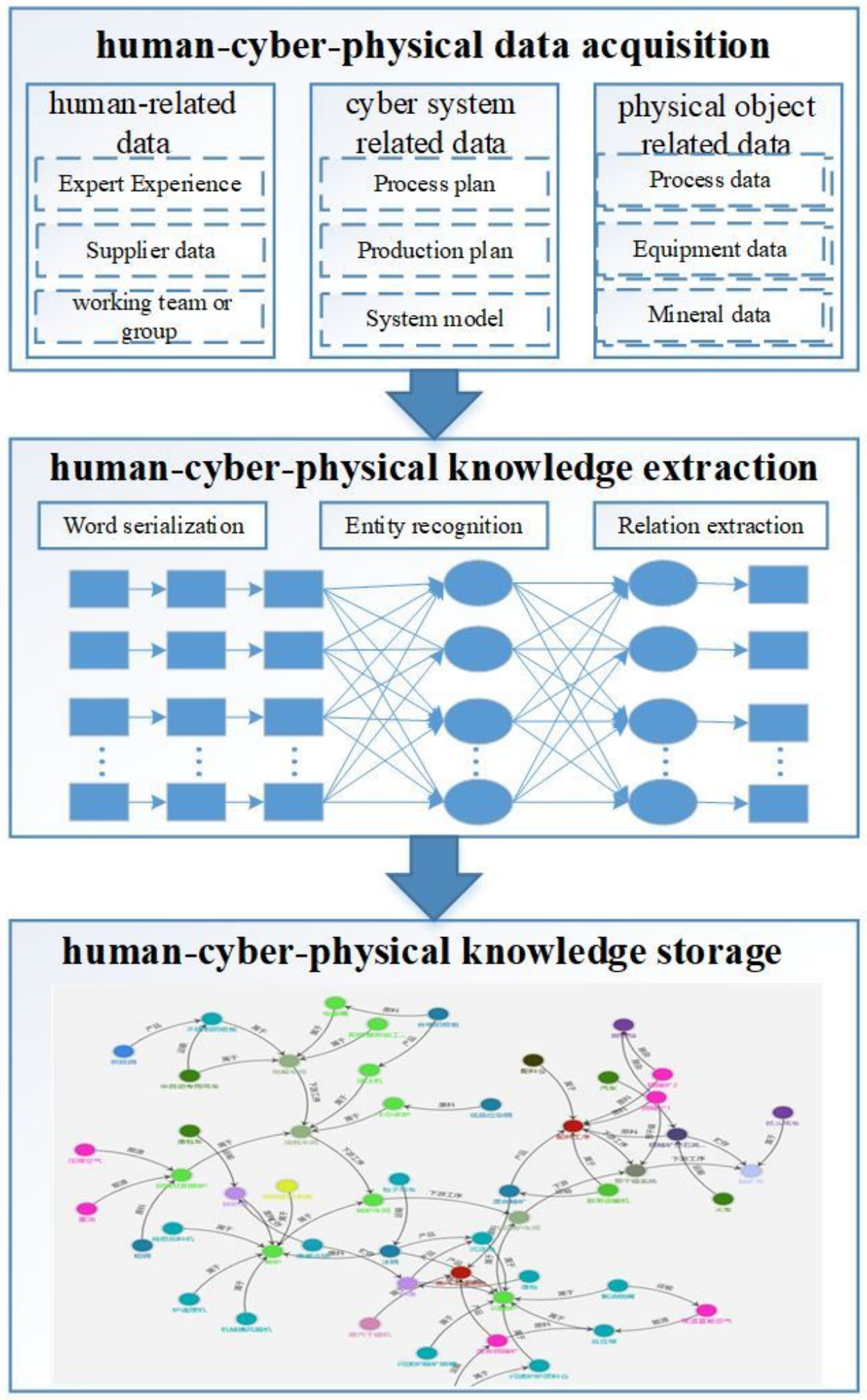

Figure 9

Three steps to build the human-cyber-physical knowledge graph 

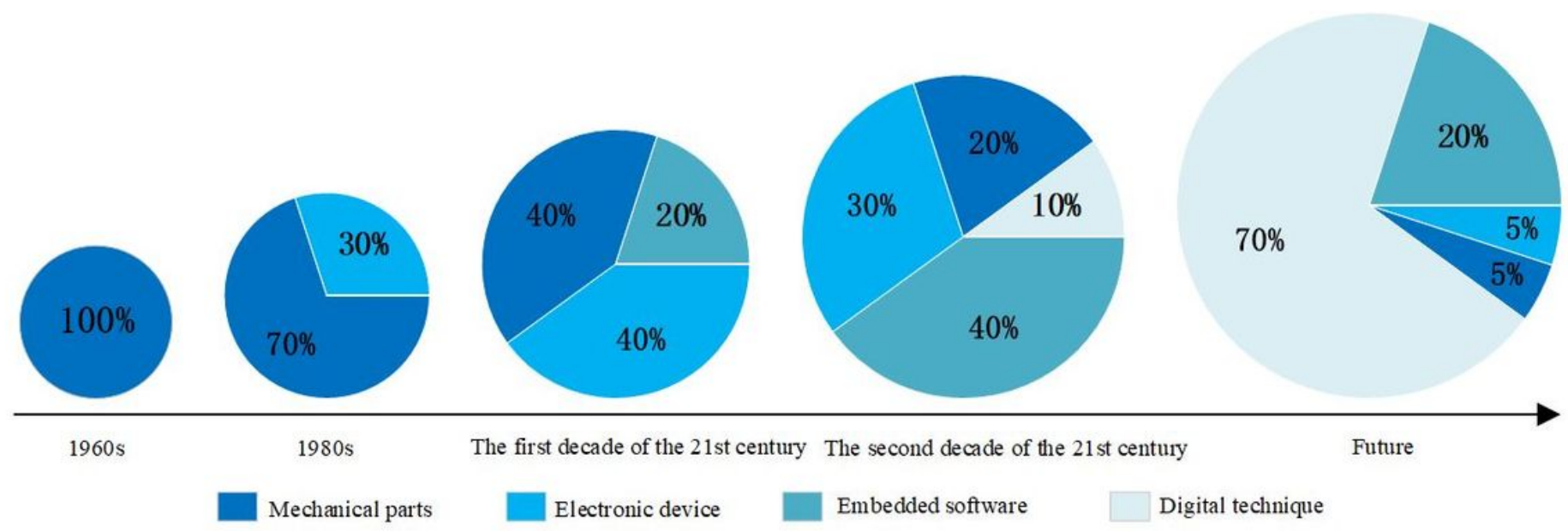

The first decade of the 21 st century The second decade of the 21 st century

Future

Mechanical parts

Electronic device

Embedded software

Digital technique

Figure 10

Evolution of product value

Structure of past products

Structure of future products
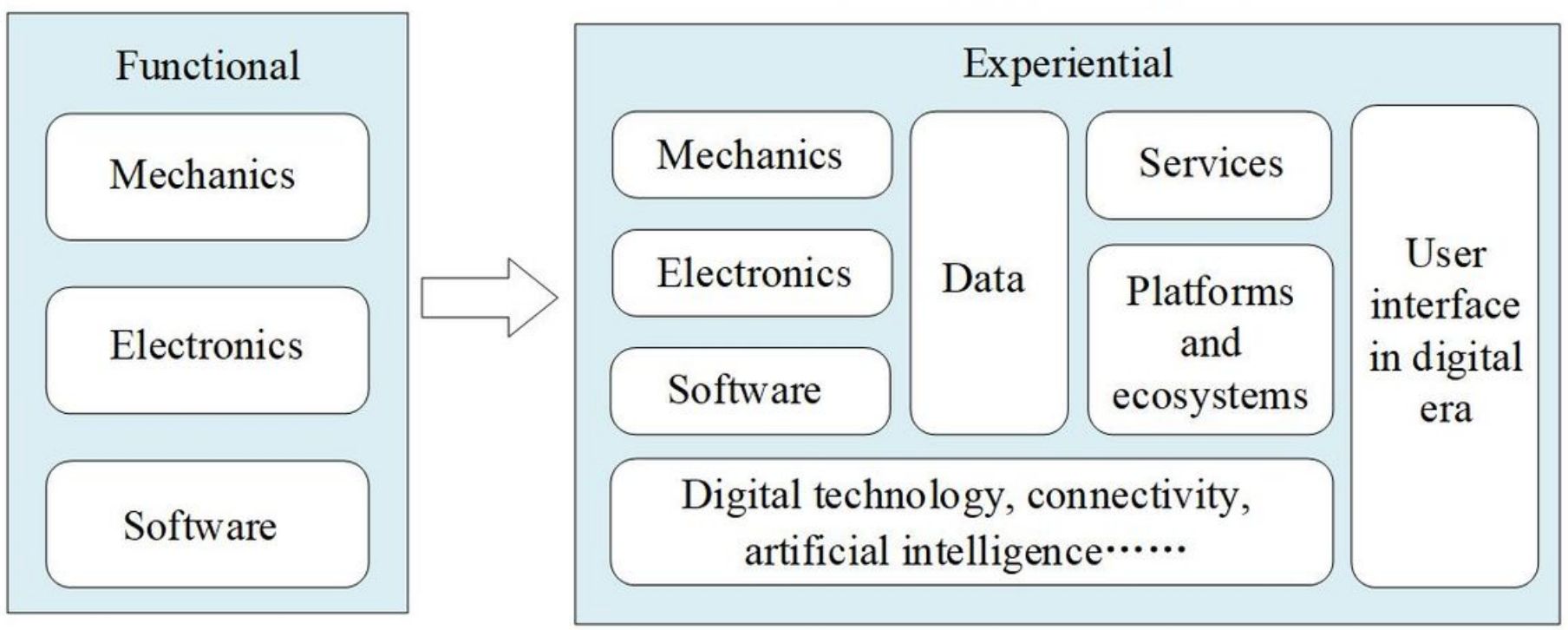

Figure 11

Changes in product structure 


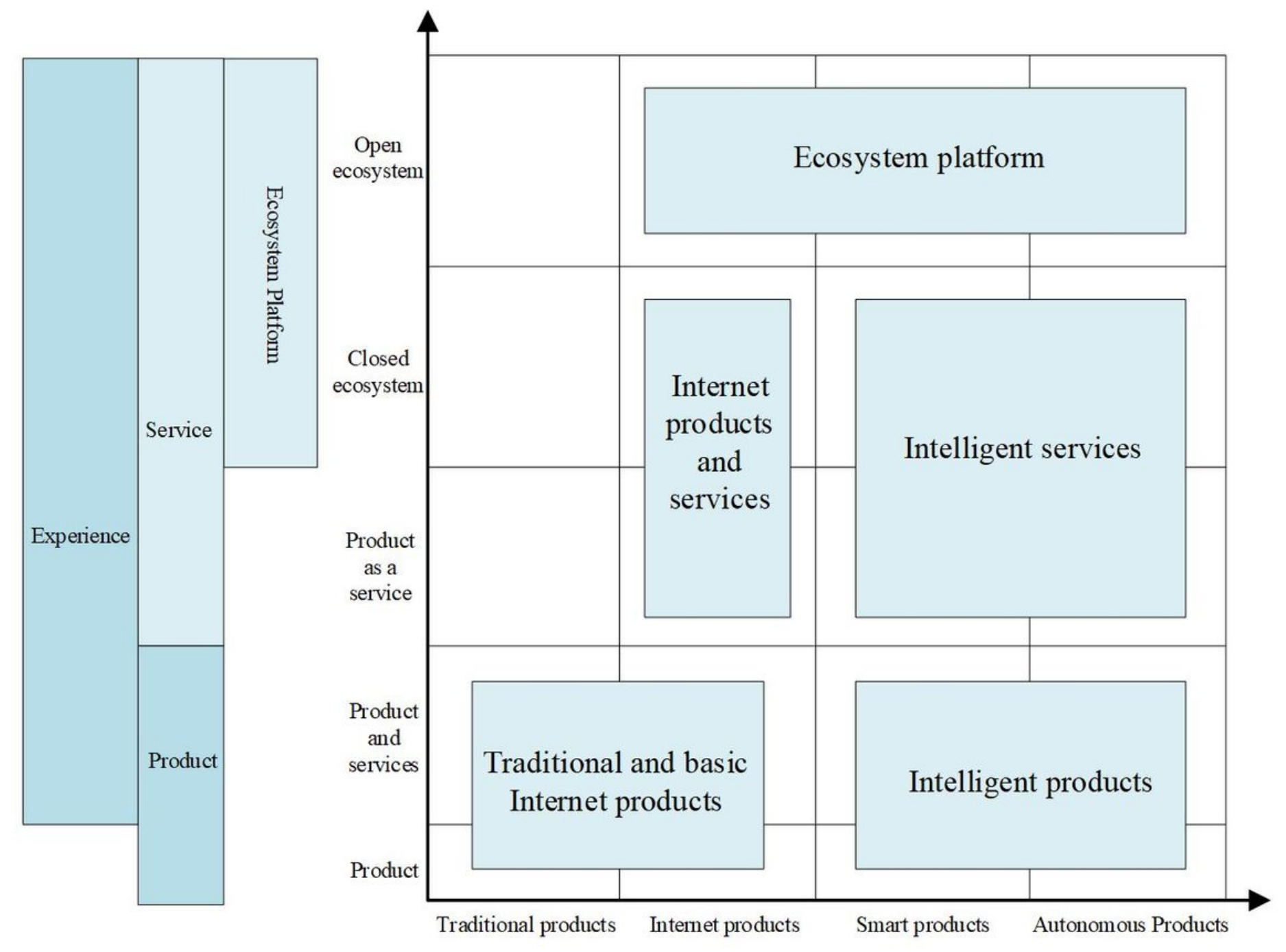

Figure 12

Corresponding structure of products and services

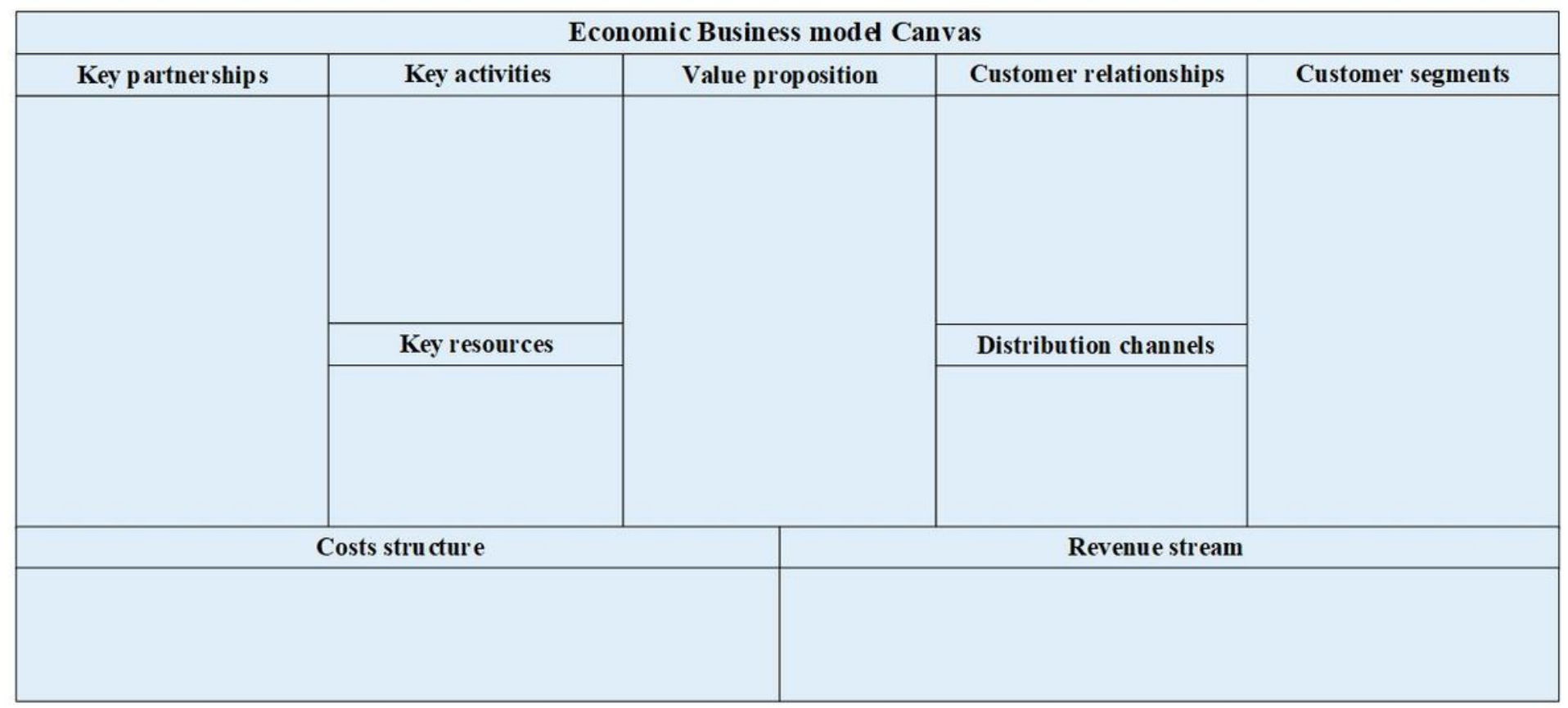


Figure 13

Economic business model canvas

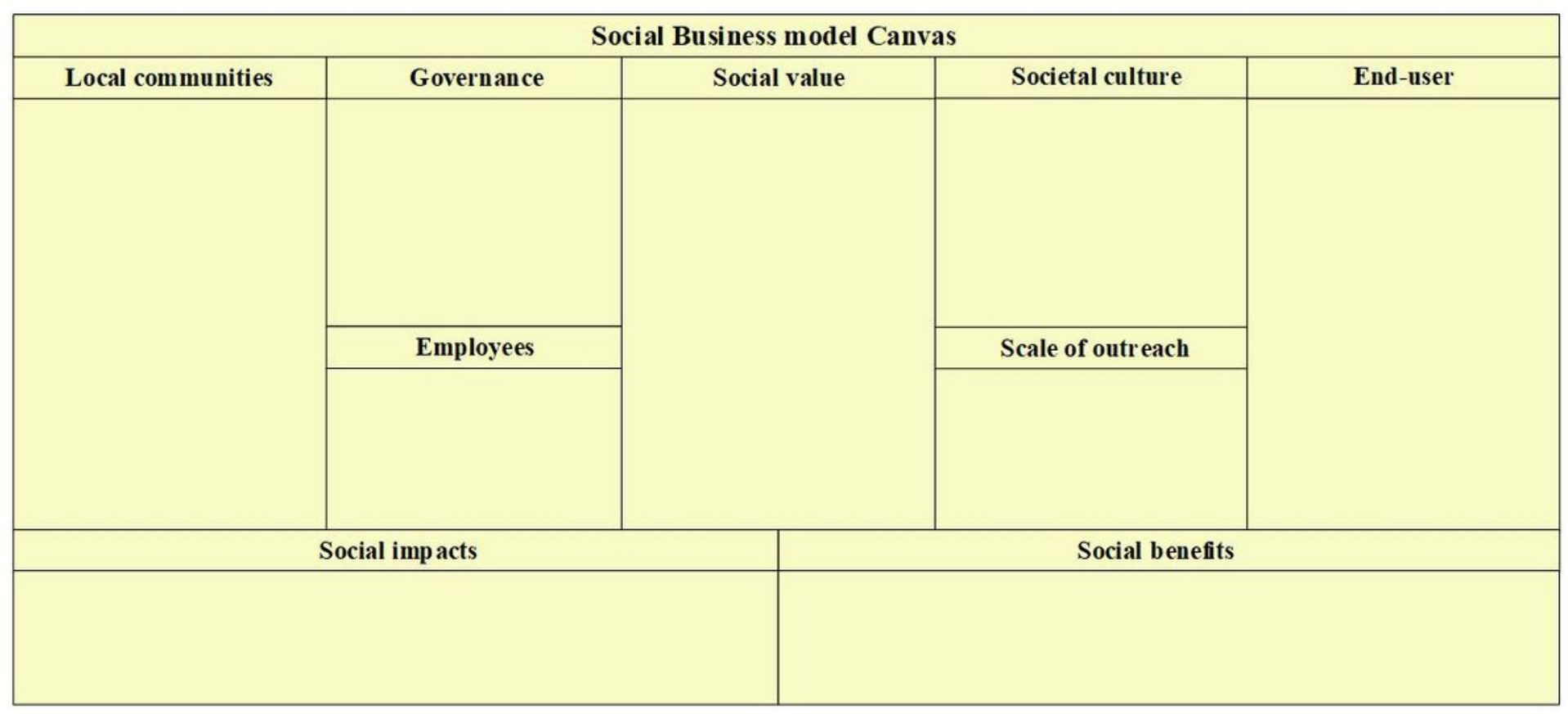

\section{Figure 14}

Social business model canvas

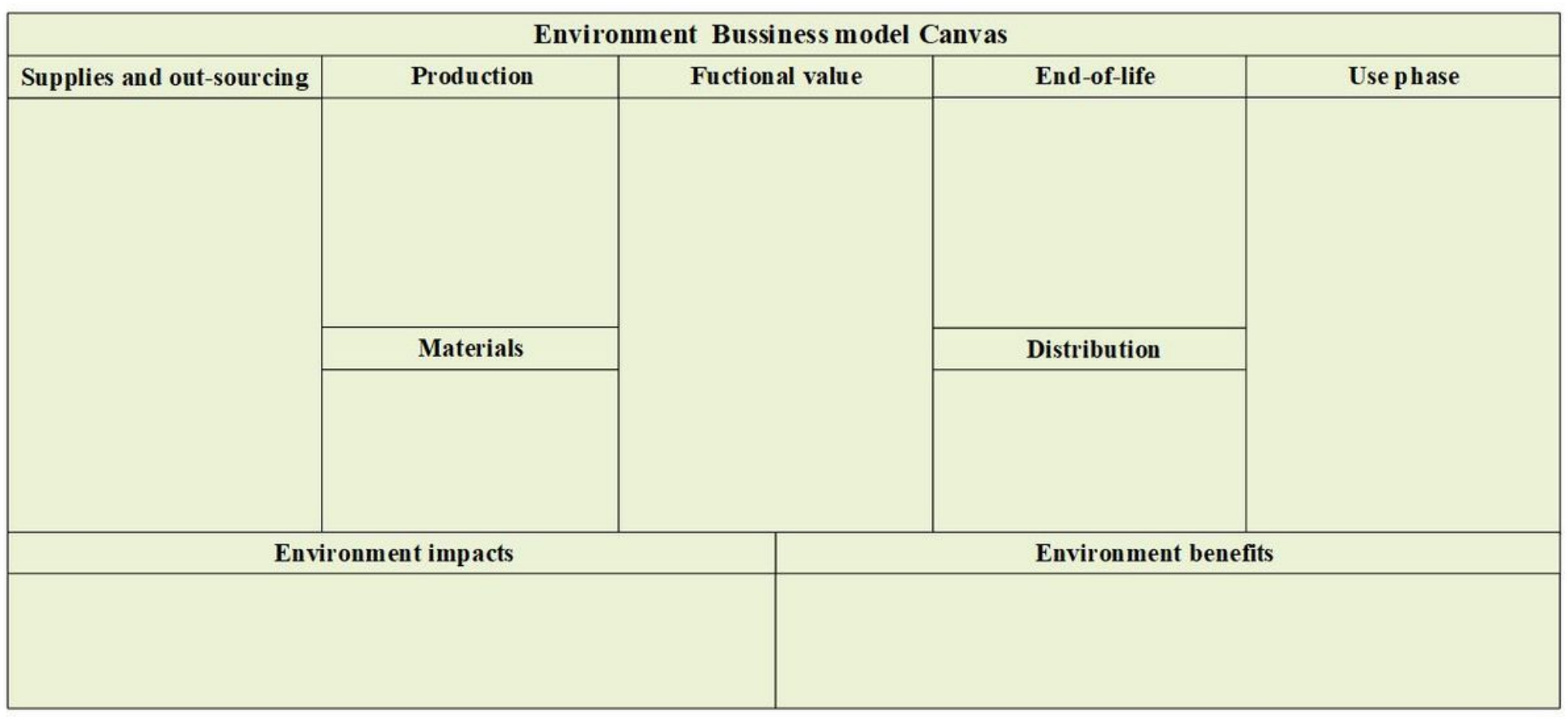

\section{Figure 15}

Environmental business model canvas 


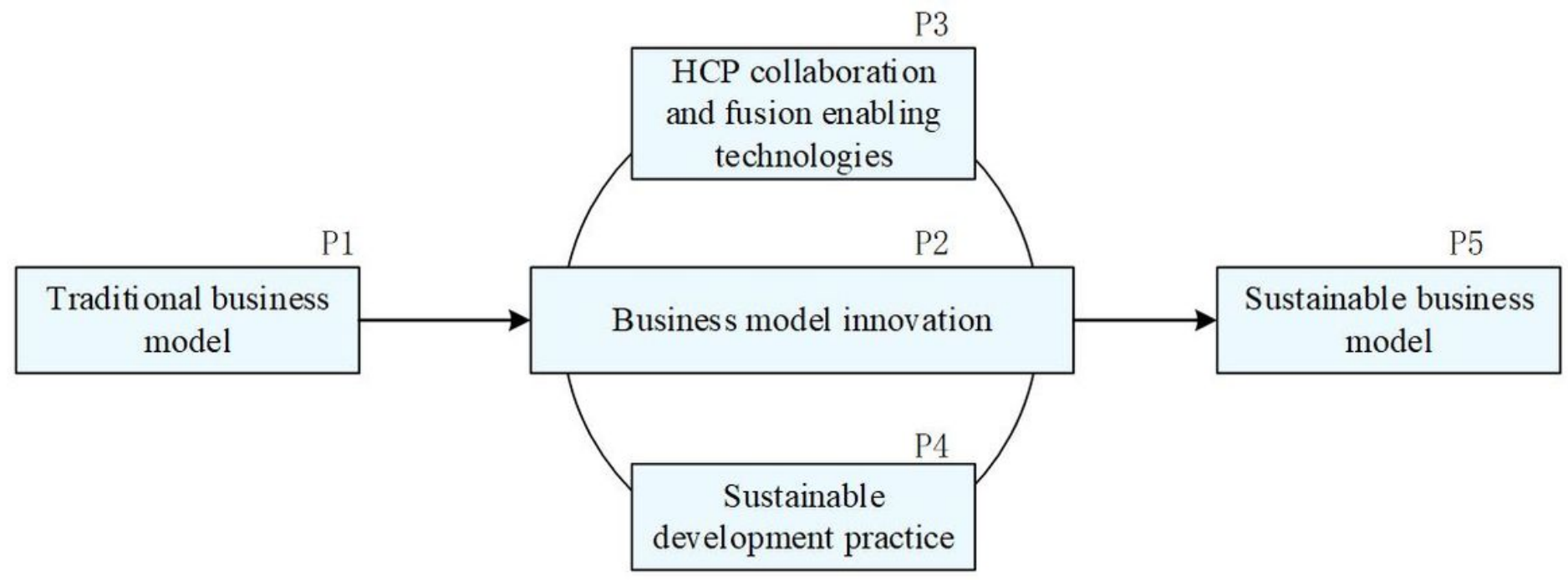

Figure 16

The framework of BMI 


\section{Application of Intelligent manufacturing system with HCP collab or ation and fusion in copper smelting processes}

In telligent manufacturing system with HCP collaboration and fusion in Nonferrous metal in dustry

Cross layer-domain optimal control of $m$ ain process

1.Intelligent perception of energy and material flow

2. Cross layer prediction and simulation system

3. Cross layer optimization and control system
Joint optim ization of p redictive mainten anceand sched uling

1.Equipment intelligent prediction and plan management

2.Production scheduling and configuration

3.Joint scheduling optimization
Integration plan of production, supply and marketing

1.Production / purchase / sales plan

2.Integrated planning simulation system

3.Integrated planning decision system

\section{Human cyber system interface (interface components and tools) \\ HCI interface based on VUI / GUI / DUI}

\section{Intelligent collab orative manufacturing system platform}

(It has the functions of supply chain management, scheduling production, quality control, logistics and decision-making) 1.Platform function; 2. Standard Specification System; 3. Information security protection; 4. Operation guarantee mechanism;

\begin{tabular}{|c|c|c|c|c|}
\hline \multicolumn{4}{|c|}{$\begin{array}{l}\text { Rem ote m an agement analysis and d ecision system based on new generation AI } \\
\text { (Man agement / an alysis / decision compon ents and tools) } \\
\text { 1. Ubiquitous perception; 2, real-time analysis; } 3 \text {, independent decision-making; } 4 \text {, learning promotion }\end{array}$} & \multirow{5}{*}{$\begin{array}{c}\text { Digital } \\
\text { twin: } \\
\text { equipment } \\
\text { process / } \\
\text { workshop } \\
\text { process }\end{array}$} \\
\hline \multirow{4}{*}{$\begin{array}{l}\text { Data } \\
\text { space: } \\
\text { product/ } \\
\text { manufact } \\
\text { uring } \\
\text { /manage } \\
\text { ment }\end{array}$} & $\begin{array}{l}\text { Cross layer-dom ain optim al control } \\
\text { 1) Multi topic data cross domain integration } \\
\text { 2) Cross domain service sharing } \\
\text { 3) Process cross domain management } \\
\text { 4) Cross layer-domain optimization analysis, } \\
\text { simulation, decision and control of key } \\
\text { processes }\end{array}$ & $\begin{array}{l}\text { Predictive operation } \\
\text { 5) Predictive maintenance and health } \\
\text { management of equipment } \\
\text { 6) Forecast and analysis of key process } \\
\text { operation status } \\
\text { 7) Product quality prediction based on } \\
\text { operation status } \\
\text { 8) Production forecast of products and } \\
\text { accessories }\end{array}$ & $\begin{array}{l}\quad \text { Int egr at ed plan } \\
\text { 9) Production plan management } \\
\text { 10) Purchasing plan management } \\
\text { 11) Sales plan management } \\
\text { 12) Integrated plan management of } \\
\text { production, supply and marketing }\end{array}$ & \\
\hline & \multicolumn{3}{|c|}{$\begin{array}{l}\text { Interface: 1. Data transmission, storage, display and control; 2. Portable maintenance assistant; } 3 \text {. Spare parts inventory and } \\
\text { production of fline optimization; } \\
\text { Functions: } 1 \text {. Modeling of Cyber-physical system (Digital Twin); 2. Digital Twin based Adjustment and Control }\end{array}$} & \\
\hline & \multicolumn{3}{|c|}{$\begin{array}{l}\text { Equipment autonomous control system (sel-optimizing control components and tools) } \\
\text { 1. Intelligent perception; 2. Intelligent analysis and decision; 3. Autonomous control }\end{array}$} & \\
\hline & \multicolumn{3}{|c|}{$\begin{array}{l}\text { Process unit system } \\
\text { 1. Equipment body (working devices and power devices); } 2 \text {. Sensing system (sensing devices); } 3 \text {. Servo executive system } \\
\text { (actuators); 4. Human machine interface HMI based on VUI / GUI }\end{array}$} & \\
\hline \multicolumn{5}{|c|}{ Fine control process of copper smelting } \\
\hline \multicolumn{5}{|c|}{ Multi production-base, multi production line and multi process flow } \\
\hline
\end{tabular}

\section{Figure 17}

Architecture of the intelligent manufacturing system with HCP collaboration and fusion in a non-ferrous metal enterprise 


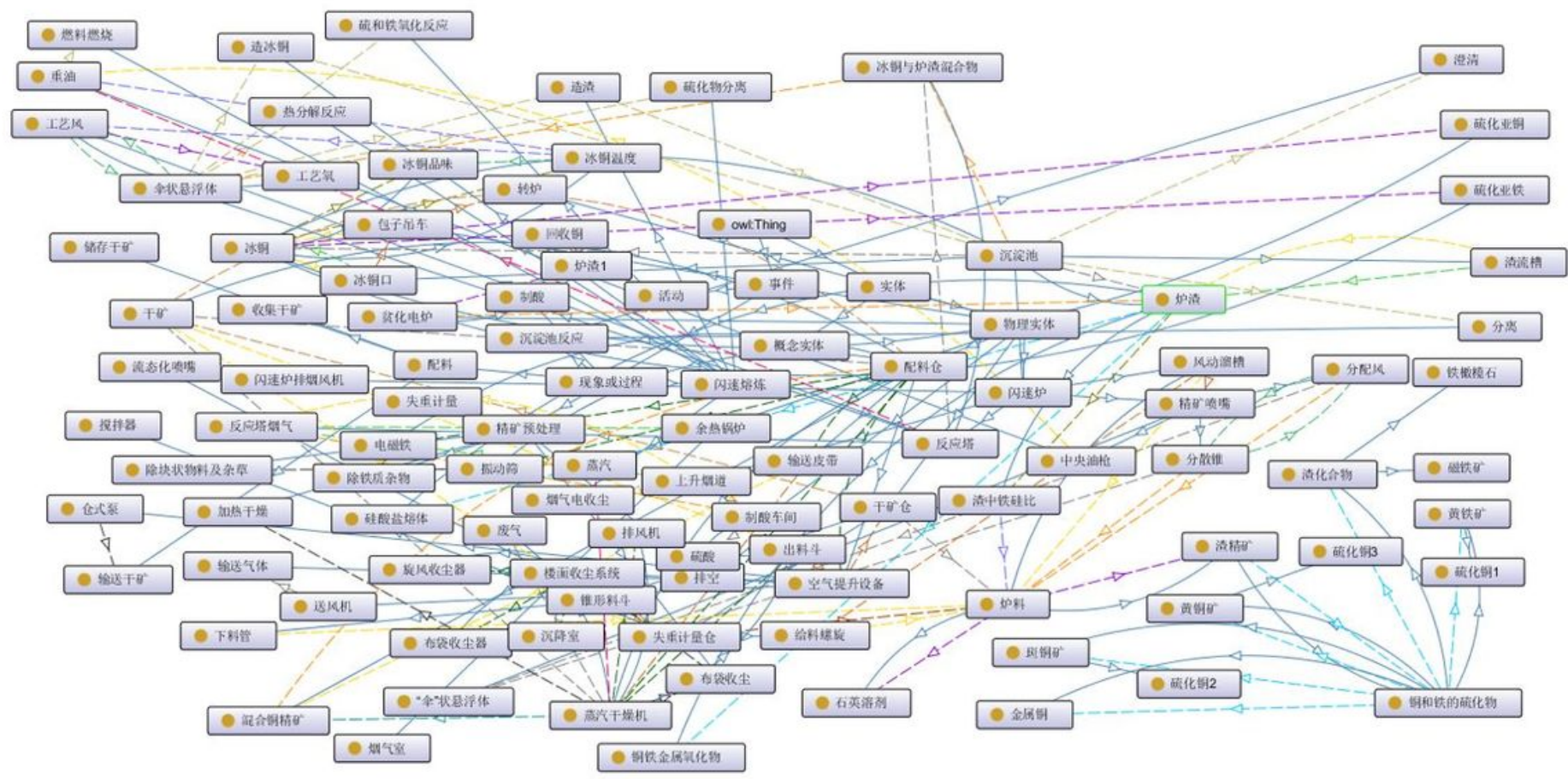

Figure 18

A domain knowledge graph for flash furnace production process

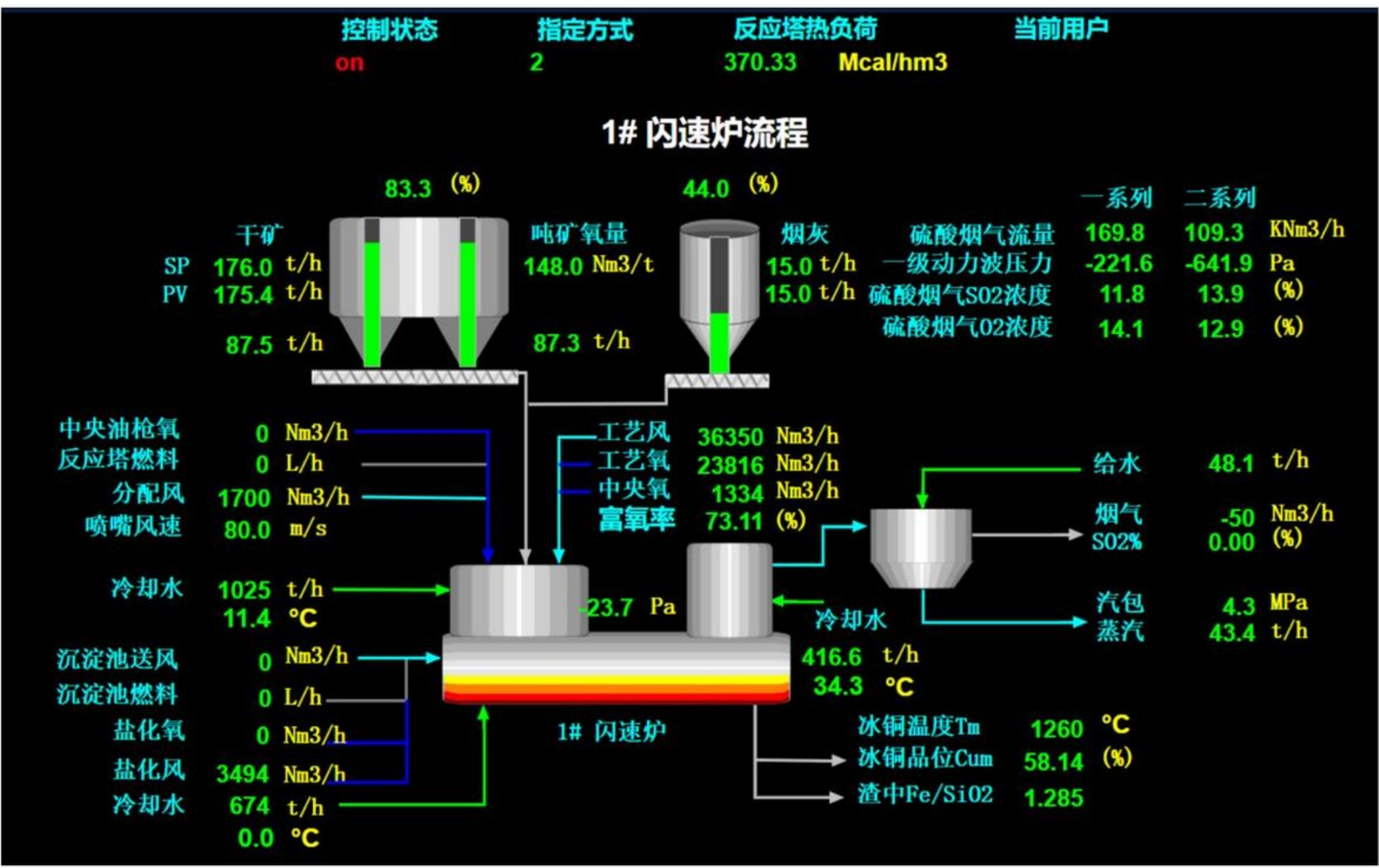


Figure 19

The mechanism and data based flash furnace melting twin model

\section{Ecosystem service platform of Jiangxi Copper Group}

\begin{tabular}{|c|c|}
\hline \multicolumn{2}{|c|}{ Platform business } \\
\hline \multicolumn{2}{|c|}{$\begin{array}{l}\text { Nonferrous metal products } \\
\text { - } \quad \text { Main products } \\
\text { - } \quad \text { Accessory products } \\
\text { - } \quad \text {....... }\end{array}$} \\
\hline \multicolumn{2}{|c|}{$\begin{array}{l}\text { Process related services } \\
\text { - } \begin{array}{l}\text { Intelligent production } \\
\text { related services }\end{array} \\
\text { Digital transformation } \\
\text { related services } \\
\text {-..... }\end{array}$} \\
\hline \multicolumn{2}{|c|}{ Platform participants } \\
\hline Enterprise & Customer \\
\hline
\end{tabular}

Figure 20

Framework of the ecosystem service platform for the Jiangxi Copper Group 


\begin{tabular}{|c|c|c|c|c|}
\hline \multicolumn{5}{|c|}{ Economic Business model Canvas } \\
\hline Key partnerships & Key activities & Value proposition & Customer relationships & Customer segments \\
\hline \multirow[t]{3}{*}{$\begin{array}{l}\text { 1)Raw material suppliers } \\
\text { 2)Equipment and machinery } \\
\text { suppliers } \\
\text { 3)Suppliers of electricity } \\
\text { 4)IT solution providers } \\
\text { 5)Logistics service provider } \\
\text { 6)Financial services providers }\end{array}$} & $\begin{array}{l}\text { 1)Purchase、 Marketing and } \\
\text { sales } \\
\text { 2)Process planning } \\
\text { 3)Manufacturing of Copper } \\
\text { 4)Facilities operations \& } \\
\text { maintenance }\end{array}$ & \multirow[t]{3}{*}{$\begin{array}{l}\text { 1))Provide cost-effective non- } \\
\text { ferrous metal products }\end{array}$} & 1)Supply relationship & \multirow[t]{3}{*}{$\begin{array}{l}\text { 1)Deep processing industry } \\
\text { customers (wire, pipe, etc.) } \\
\text { 2)Application industry } \\
\text { customers (electric power, } \\
\text { home appliances, etc.) }\end{array}$} \\
\hline & Key resources & & Distribution channels & \\
\hline & $\begin{array}{l}\text { 1)Mine } \\
\text { 2)Smelting technology } \\
\text { 3)Financial assets }\end{array}$ & & 1)Offline sa les network & \\
\hline \multicolumn{2}{|r|}{ Costs structure } & \multicolumn{3}{|c|}{ Revenue stream } \\
\hline \multicolumn{2}{|l|}{$\begin{array}{l}\text { 1)Manufacturing costs } \\
\text { 2)Research \& development costs } \\
\text { 3)Equipment maintenance }\end{array}$} & \multicolumn{2}{|c|}{$\begin{array}{l}\text { 1)Product sales } \\
\text { 2)Product processing }\end{array}$} & \\
\hline
\end{tabular}

\section{Figure 21}

Economic business model canvas of Jiangxi Copper Group (before BMI)

\begin{tabular}{|c|c|c|c|c|}
\hline \multicolumn{5}{|c|}{ Economic Business model Canvas } \\
\hline Key partnerships & Key activities & Value proposition & Customer relationships & Customer segments \\
\hline \multirow[t]{3}{*}{$\begin{array}{l}\text { 1)Raw material suppliers } \\
\text { 2)Plant and machinery suppliers } \\
\text { 3)Suppliers of electricity } \\
\text { 4)IT solution providers } \\
\text { 5)Logistics service provider } \\
\text { 6)Financial services providers } \\
\text { 7)Third party service provider }\end{array}$} & $\begin{array}{l}\text { 1) Intelligent purchasing, } \\
\text { marketing and sales } \\
\text { 2) Intelligent smelting and } \\
\text { processing } \\
\text { 3) Predictive maintenance } \\
\text { and management of } \\
\text { equipment } \\
\text { 4) Operate service platform } \\
\text { and service provision }\end{array}$ & \multirow[t]{3}{*}{$\begin{array}{l}\text { 1))Provide cost-effective non- } \\
\text { ferrous metal products } \\
\text { 2)Provide customer-centric } \\
\text { service }\end{array}$} & $\begin{array}{l}\text { 1)Supply relationship } \\
\text { 2)Partners }\end{array}$ & \multirow[t]{3}{*}{$\begin{array}{l}\text { 1)Deep proces sing industry } \\
\text { customers (wire, pipe, etc.) } \\
\text { 2)Application industry } \\
\text { customers (electric power, } \\
\text { home appliances, etc.) } \\
\text { 3)Customers with demand for } \\
\text { paltform services }\end{array}$} \\
\hline & Key resources & & Distribution channels & \\
\hline & $\begin{array}{l}\text { 1)Mine } \\
\text { 2)Smelting technology } \\
\text { 3)Financial assets } \\
\text { 4) Ecosystem service platform }\end{array}$ & & $\begin{array}{l}\text { 1)Offline sa les network } \\
\text { 2)Online sales network }\end{array}$ & \\
\hline \multicolumn{2}{|c|}{$\begin{array}{l}\text { Costs structure } \\
\end{array}$} & \multicolumn{3}{|c|}{ Revenue stream } \\
\hline \multicolumn{2}{|c|}{$\begin{array}{l}\text { 1)Manufacturing costs } \\
\text { 2)Research \& development costs } \\
\text { 3)Equipment maintenance and management } \\
\text { 4)Platform ma intenance and management }\end{array}$} & $\begin{array}{l}\text { 1)Product sa } \\
\text { 2)Product pr } \\
\text { 3) Service ch } \\
\text { 4)Platform c }\end{array}$ & $\begin{array}{l}\text { s } \\
\text { ge } \\
\text { nmission }\end{array}$ & \\
\hline
\end{tabular}

\section{Figure 22}

Economic business model canvas of Jiangxi Copper Group (after BMI) 


\begin{tabular}{|c|c|c|c|c|}
\hline \multicolumn{5}{|c|}{ Environment Bussiness model Canvas } \\
\hline Supplies and out-sourcing & Production & Fuctional value & End-of-life & Use phase \\
\hline \multirow{9}{*}{$\begin{array}{l}\text { 1) Electricity } \\
\text { 2) Water } \\
\text { 3) Methane } \\
\text { 4) Laboratory equipment } \\
\text { 5) Laboratory consumables }\end{array}$} & 1) Melting process & \multirow{9}{*}{$\begin{array}{l}\text { 1) One ton of copper multiplied } \\
\text { by one ton of copper in a year } \\
\text { total output }\end{array}$} & \multirow[t]{4}{*}{ 1) Copper scrap disposal } & \multirow{9}{*}{ 1) Maintenance } \\
\hline & 2) Blowing process & & & \\
\hline & 3) Refining process & & & \\
\hline & 4) Electrolysis process & & & \\
\hline & Materials & & Distribution & \\
\hline & 1) Copper concentrate & & \multirow{4}{*}{$\begin{array}{l}\text { 1) Truck transport } \\
\text { 2) Shipping } \\
\text { 3) Train transportation }\end{array}$} & \\
\hline & 2) Quartz sand & & & \\
\hline & 3) Slag concentrate & & & \\
\hline & 4) Ingredients & & & \\
\hline \multicolumn{2}{|c|}{ Environment impacts } & \multicolumn{3}{|c|}{ Environment benefits } \\
\hline \multirow{3}{*}{$\begin{array}{l}\text { 1) Air pollution } \\
\text { 2) Soil pollution } \\
\text { 3) Water pollution }\end{array}$} & & & $\begin{array}{l}\text { 1) Industrial water cycle } \\
\text { 2) Heap leaching of waste rock }\end{array}$ & $\begin{array}{l}\text { 5) Copper separation from waste residue } \\
\text { 6) Waste heat power generation }\end{array}$ \\
\hline & & & 3) Acid production from flue gas 7) & y saving and environmental \\
\hline & & 4) Copper extr & action from wastewater pro & \\
\hline
\end{tabular}

\section{Figure 23}

\section{Environmental business model canvas of Jiangxi Copper Group (after BMI)}

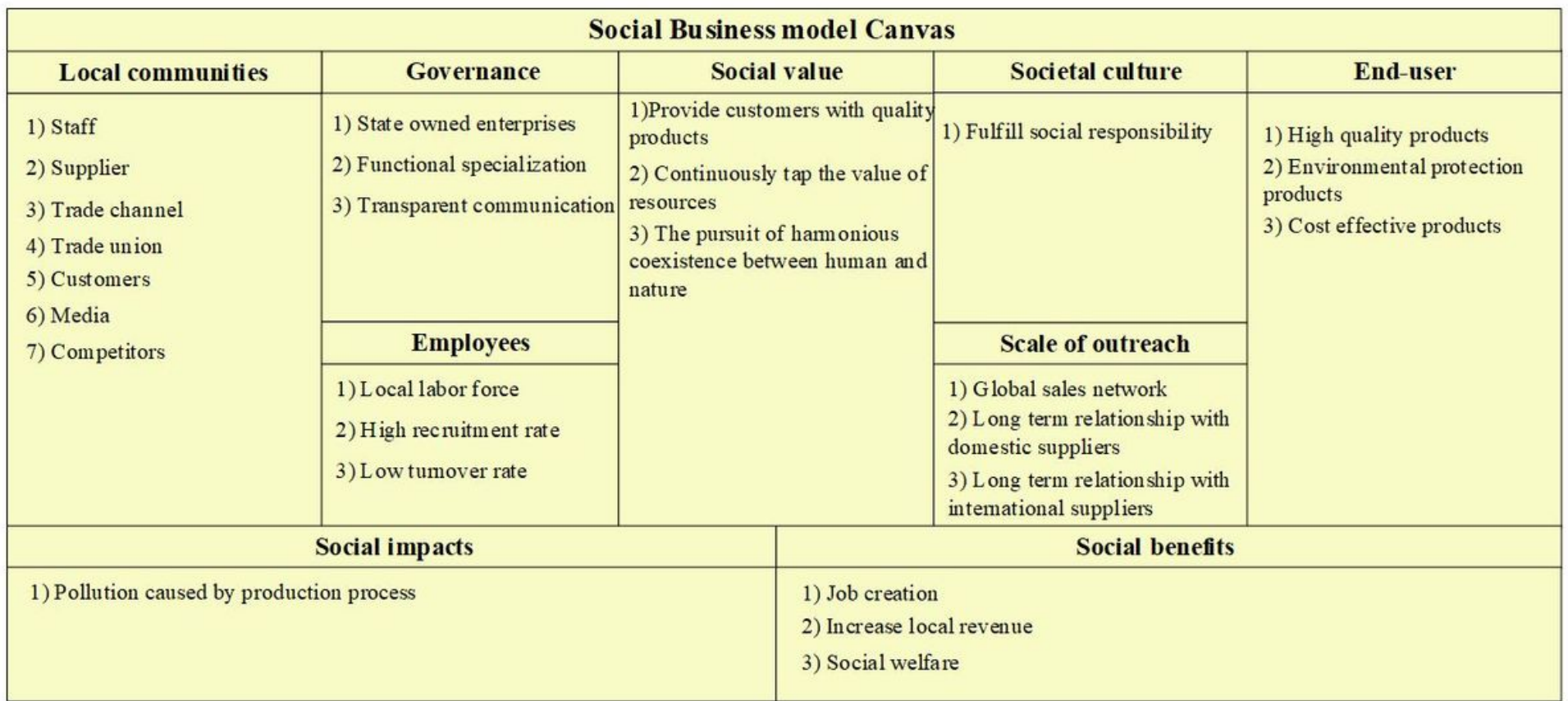

\section{Figure 24}

Social business model canvas of Jiangxi Copper Group (after business model reform) 